\title{
DigitalCommons@NYLS
}

Articles \& Chapters

Faculty Scholarship

1990

\section{Afterword: Studying Litigation and Social Change}

Frank W. Munger

New York Law School, frank.munger@nyls.edu

Follow this and additional works at: https://digitalcommons.nyls.edu/fac_articles_chapters

Part of the Courts Commons, and the Litigation Commons

\section{Recommended Citation}

Munger, Frank W., "Afterword: Studying Litigation and Social Change" (1990). Articles \& Chapters. 1360.

https://digitalcommons.nyls.edu/fac_articles_chapters/1360

This Article is brought to you for free and open access by the Faculty Scholarship at DigitalCommons@NYLS. It has been accepted for inclusion in Articles \& Chapters by an authorized administrator of DigitalCommons@NYLS. 


\title{
AFTERWORD: STUDYING LITIGATION AND SOCIAL CHANGE
}

\author{
FRANK MUNGER
}

In the course of planning the conference that led to this issue of the Review and while these essays were being prepared, I had an opportunity to consider what my colleagues said and wrote about longitudinal studies of trial courts in the broader context of research on law and society. As Lawrence Friedman comments at the beginning of this Special Issue, only a small number of scholars have actually pursued studies of courts over time; yet, this work speaks to issues that hold the interest of many. In this Afterword I would like to add my own observations about developments that hold promise for studies of law and society as well as for longitudinal research on trial courts. These observations reflect the perspective of many of the essays here that trial courts are a site for research about law and change rather than a specific object of research. Indeed, I will argue that trial courts may not be separated from their social context and that to study them is to simultaneously study issues relevant to many law and society subfields.

\section{SOCIAL CHANGE}

The most important contribution of longitudinal research on trial courts is its systematic attention to social change. Generally speaking, because all social action is dynamic, it is important that we develop temporal views of action, organization, and culture through our research. In particular, actions influenced or constituted by legal institutions are part of processes taking place over time, and examining them over time seems essential to a full understanding how law might be implicated in their origins, in the ways that they unfold and in their effects (see Moore, 1990). These discoveries, in turn, will illuminate processes that are basic to law's role in society.

Critics have argued that earlier research on law and social change focused exclusively on the gap between the intended and actual effects of law, ignoring both the law's displacement of alternative conceptions of order and its constitutive role in maintaining

LAW \& SOCIETY REVIEW, Volume 24, Number 2 (1990) 
everyday and routine social life. ${ }^{1}$ Such criticism raises questions concerning what studies of law and social change should be about. Few have attempted to describe appropriate alternative theoretical frames of reference, but by drawing on essays here, I would like to suggest that not only are alternative frameworks for the study of law and social change beginning to emerge from longitudinal research on trial courts, but also that the temporal dimension they incorporate is of vital significance for our understanding of law and society more generally.

\section{A. Small-Scale, Multicausal Models}

First, longitudinal research on trial courts affirms a conclusion reached by Richard Abel (1980), in his review of law and society research a decade ago, that it is the interaction of legal institutions and society on many levels that is interesting and important. ${ }^{2}$ The picture emerging from recent research on trial courts reveals a multicausal interaction in the form of many interlocking smallscale processes among actors. For example, contrast a classic impact study of the effects of court decisions on the behavior of toxic tortfeasors with the complex understanding of litigation that underlies the concept of "case congregation" described herein by Marc Galanter, a concept that incorporates into the relationship between a court and its environment the network of interactions between courts and lawyers, lawyers and clients, and lawyers and other lawyers that evolves over time to produce a distinct longitudinal pattern of asbestos or DES litigation. As Sanders suggests in this issue, at this stage of our understanding of the relationship between law and society it seems both necessary and theoretically appropriate to explore how such interlocking small-scale processes operate in order to understand how larger aggregate patterns are created and changed.

1 Reviewing law and society research a decade ago, Richard Abel (1980) argued that concern for legal effectiveness, a concern embedded in the ideological premises of the legal system itself, so dominated theories about law and social change that research was limited to impact studies-studies that examined the law's effectiveness in producing behavior conforming with legal norms. In a related criticism, Austin Sarat and Susan Silbey (1988) have suggested that the field's fascination with policy questions focused law and society research on the gap between legal ideals and institutional practices. Studies of law and social change, they argued, ignored both the law's displacement of alternative conceptions of order and its constitutive role in maintaining the everyday and routine patterns of social life. Both criticisms have suggested that research on law and social change has often served to reinforce the ideological premises for the legal system itself.

2 Although Abel uses the term "function" to describe the role of legal institutions in society, feedback mechanisms seldom exist to link the effects of law with the behavior of participants in legal institutions. Thus, "functional" is inappropriate as a formal theoretical concept describing law's causal role. Nor do I believe that Abel uses the term in its formal sense. As I discuss further in note 7, the purposive and instrumental quality of legal behavior is captured better by another theoretical concept, "intentional" causation. 


\section{B. Closing the Gap: Merging "Court-centered" and "Dispute- centered" Research}

Longitudinal research also clearly reveals that trial courts and communities are linked on many levels. Indeed, one emerging realization is that legal institutions and community interpenetrate so thoroughly that legal institutions simply cannot be understood without explicit attention to their community context. This insight is inconsistent with any meaningful distinction between "dispute-centered" and "court-centered" trial court research, a distinction that has been used to characterize longitudinal trial court research depending on whether the interest of the researcher is the origin and processing of disputes or the work of the courts (Friedman, 1989b). ${ }^{3}$ The characterization of the field as made up of dispute-centered and court-centered research also risks perpetuating the theory that courts are independent, neutral processors of disputes, rather than part of a legal system that is intertwined with disputing and conflict in the society.

Studies of courts over time show that we cannot maintain the distinction between "dispute-centered" and "court-centered" approaches to understanding the interconnections between legal institutions and community. Legal institutions and their ideology may be deeply embedded in community life (Merry, 1985), constitute an omnipresent and potent alternative to traditional means of dispute resolution (Yngvesson, 1985b; Merry, 1982; Cooter and Rubinfeld, 1990) and underlie the tensions created by efforts to remain outside of the influence of legal culture (Greenhouse, 1986; Moore, 1978; Engel, 1984).

Research that purports to be court-centered is equally about the relationship between law and community. Definitions of conflict, the legitimacy of nonlegal authority, and the influence of the social organization of the community (and the state) on the perceptions and actions of courts and court personnel are issues for court-centered research. Lempert's reconstruction (1990) of his longitudinal study of the Hawaii Housing Authority demonstrates that these influences may alter the significance of formal outcomes for both disputants and tribunal or far outweigh them in importance. Such findings are also a reminder that "court-centered" research should not focus exclusively on formal or intended effects of legal decisions or legal change. ${ }^{4}$ Therefore, investigators must

3 I disagree with Friedman's characterization of most longitudinal litigation research as court-centered, because the goal of most researchers is in fact to explain the origin and processing of disputes, and the court as a separate entity is treated as mere recordkeeper, playing little or no role in the explanation of disputing or litigation.

4 This perhaps explains why there has been surprisingly little interest in formal litigation outcomes in studies of the relationship between community change and trial courts (Friedman, 1989b), since community and courts are intertwined in so many other significant ways. In a different theoretical frame of reference outcomes have been of great interest to those attempting to un- 
recognize that courts and disputes are part of the same social and political processes of conflict and conflict resolution in society.

\section{Incorporating a Temporal Perspective into Theory}

The temporal perspective of longitudinal research should improve our theories of what happens when courts and community interact. Some illustrations will demonstrate how a temporal perspective contributes new insights about the role played by trial courts and, more generally, by law.

Continuing Relations. One of the central insights of law and society research has been the continuing relations hypothesis (Macaulay, 1963; Lempert and Sanders, 1986; Blegvad, 1990), which characterizes relationships as either episodic or continuing and predicts greater use of law to resolve conflict by parties in episodic relationships than by parties in continuing relationships. The insight has become an axiom in cross-sectional research. Yet, its fullest implications are longitudinal, for in longitudinal perspective it is possible to see that the maintenance of continuing relations is always problematic and must be explained just as the maintenance of all forms of social order must be explained. Viewed in a longitudinal perspective, legal institutions, including trial courts, may contribute to either maintaining or changing the reciprocity underlying a continuing relationship (Engel, 1984; Blau, 1964). Further, over time, many continuing relations are maintained through hierarchy rather than through reciprocity, and the law's role in contributing to the maintenance of such a continuing relationship is an important issue (Yngvesson, 1985a). Simply classifying types of relationships as continuing, without examining the processes by which they continue or change, conflates actor choices and the social structure within which actors make choices about dispute resolution. By viewing continuing relations as a process taking place over time, we discover the contingent alternatives-the social structures-that shape actors' choices at a given moment. The presence of choice gives us something to explain, and as David Engel observed (1990) in his essay in this issue, ongoing change produces conflicting claims and conflicting systems of dispute resolution to choose among in every society.

Actor-oriented Perspective. Research on trial courts that has incorporated the dimension of time has strongly suggested that an actor-oriented perspective is needed to detect the ambiguity created by change-induced conflict and to understand the choices made by actors from among competing interpretations and com-

derstand the internal working of courts as organizations because formal outcomes bear a much more direct relationship to the formal and informal processes within trial courts than they do to the external environment of courts (Padgett, 1990; Seron, 1990). 
peting claims of authority. Pierre Bourdieu (1977) has explained why. Because of the presence of ambiguity in the situation that an actor does but the observer does not see, individuals in the middle of a stream of events perceive the significance of their own decisions differently from the way an observer does who examines the completed sequence of events. Thus, without benefit of an actororiented perspective the observer may be unable to understand changes in the individual's behavior when they occur. Our theories about changes in the activities of trial courts and their effects will be able to explain more if they take into account the meanings that situations have for the actors that are presented with them. Authors in this issue (Yngvesson, 1990; Blegvad, 1990; Lempert, 1990; Sanders, 1990; Cooter and Rubinfeld, 1990; Mather, 1990; Galanter, 1990), and many others (e.g., Greenhouse, 1986; Friedman, 1985; Boyum, 1983; Zemans, 1983; Schwartz, 1964) make this point eloquently in their research, by showing, for example, that an individual's participation in formal dispute resolution depends on beliefs about its meaning and likely effects that may not be deducible from the "objective" perspective of a nonparticipant. Their suggestions for the development of theory may provide assistance in fashioning a systematic approach to research. For example, microeconomic theory may provide a logical framework for understanding actor choices (Cooter and Rubinfeld, 1990; Peterson and Priest, 1982). The logical structure of microeconomics may accommodate a wider range of factors than is customary in microeconomic explanations (see Sanders, 1990, for discussion and compare Edwards and Tversky, 1967). Blegvad (1990) suggests another theoretical starting point in the study of cultural orientations, or "thematizations," that result in framing similar actor choices in quite different ways (see also Luhmann, 1981).

Organizational and Institutional Actors. Longitudinal research can explore the special roles of "repeat players." Indeed, it may be necessary just to identify repeat players, because their experience or influence is accumulated over time and possibly through many different types of contacts with legal institutions. It takes longitudinal research not only to identify the "repeat players," but also to examine the effects over time of the accumulation of experience and playing for the longer run on the capacity, goals and success of repeat players in dispute resolution.

Research over time on courts convincingly demonstrates that the courts and the state are important factors, a compelling conclusion that has often been ignored. Almost unremarked in analyses of longitudinal trial court data are the changes in court processes that affect litigation-changes in court jurisdiction, or personnel, or laws affecting the legal bases for cases or the conditions under which they may be brought. Likewise, the impact of far more subtle organizational and ideological changes in court processes may 
often be present but not noted. Indeed, it has been rare for studies to look at such changes as interesting in themselves or as other than random events that require adjustments in the analysis of docket data to make litigation rates comparable over time. If such changes, initiated by the courts themselves, were systematically studied, it would be readily apparent that courts themselves are important actors in shaping perceptions of what constitutes a litigable ."case" (Galanter, 1990), in reflecting the competition among groups contending for power through control of the jurisdiction of the courts (Stookey, 1990), as a measure of the impact of professionalization of roles within the legal system (Padgett, 1990; Seron, 1990), as an indicator of local or national policymaking (Heydebrand, 1990; Monkkonen, 1990), and as a manifestation of the power of the state in community life generally (Moore et al., 1990).

Thus, longitudinal research on courts is important for the development of theory because the presence of temporal processes that give rise to, maintain, or change the social organization of law may easily be overlooked in studies of law at a single point in time. Longitudinal research seems particularly suited to studying the effects of processes that make legally significant relationships and meanings contingent and to studying actors whose power uniquely fits them to exert influence over the longer run.

\section{THEORY}

Critics of longitudinal studies have noted the need for greater precision of thought about the processes of litigation and change (Krislov, 1983; Daniels, 1984; Munger, 1988). 5 They have also argued that, unlike the relatively narrow theoretical focus of previous studies, a broad range of ideas might be explored by means of research on trial courts over time. Both suggestions direct researchers to pay more attention to theory, for theory focuses both data collection and analysis on particular questions. A proposition so basic to social science research might once have required no further discussion. But, because important questions have been raised about the usefulness of theory, both with respect to law and society research (Sarat, 1985; Peller, 1985; Trubek and Esser, 1989) and

5 Critics often point to the gap between the concepts employed and the measures constructed from statistical data or litigation rates to represent them, the often inappropriate use of statistical techniques, and the absence of detailed data about the decisions of litigants and courts. But most critics have argued that the problems of the field lie deeper, in weaknesses of conceptualization and theory. For example, critics have often begun by examining the units of analysis that docket studies have often taken for granted, "case," "court," and "dispute" (see Engel, 1980, 1990; Kidder, 1980-81; Yngvesson, 1988), arguing that the meaning of each unit of analysis depends on the perspective chosen from which to view it. Thus, a "case" means something different to a potential litigant and a court clerk; the "court" has different boundaries for the litigant, the court clerk, and the observer employing a theory of complex organizations. 
social science research more generally (e.g., Gouldner, 1970; Foucault, 1973; Unger, 1976; Harding, 1986), two points about its value in pursuit of understanding and its costs to the researcher may be helpful.

First, it must be remembered that choosing a theory is choosing a starting point. ${ }^{6}$ Recognizing that theory is necessary means recognizing that all research requires provisional commitment to assumptions and questions that guide inquiry (compare Nelson, 1988a). We have moved well beyond thinking that a dispute, case (cf. Engel, 1990), or court (cf. Seron, 1990) is an obvious or natural unit of analysis and an obvious starting point for longitudinal trial court research. A particular unit of analysis is derived from a theory that offers a provisional explanation of whatever interests the researcher. Yet, because there are no natural units of analysis, adoption of a theoretical perspective highlights another problem. There are no research questions that do not raise problems of perspective which may deeply divide the research community (Abel; 1980). While making a commitment to a theory results in more coherent and precise development of insight, a researcher may see this commitment as imposing a cost if the researcher recognizes its provisional nature and is simultaneously drawn to other theories. Of course, some theoretical premises may reflect a researcher's deeply held values (e.g., the belief that discrimination or hierarchy are central problems for law), while other premises required to develop the assumptions and questions for the particular research project do not (e.g., the choice to use interpretivist methodology to examine the context of potential litigants' decisions to use law to resolve conflict). Making values, cognitive framework, and methods explicit helps both researcher and audience interpret the research more accurately.

Second, the utility of theory lies in part in guiding the researcher to relevant data. This lesson is useful in view of the increasing emphasis on units of analysis that take their meaning from contextualization and actor orientations, for example, by looking to the parties to disputes or litigation for the definition of a "dispute" or a "case." An approach that relies on denser contextualization and greater emphasis on actor orientations fits well with the advice of the field's most constructive critics (compare,

6 A theory formulates questions for research. The mere fact that research is theory-driven has no bearing on the choice of methods for research, for example, whether they are quantitative or qualitative, observational or archivally based, or whether still other techniques or some combination of those just mentioned are selected. But the adoption of a particular theory may have important implications for the particular methods that one might use to answer questions, since some ways of gathering or studying information seem better suited to answering certain kinds of questions, and because some theories imply a particular relationship between this researcher and the subject of research, as, for example, in the case of Bourdieu's claim (1977: 8-9, 171) that a mere observer cannot understand the whole process of contract formation. 
e.g., Engel (1990) and Reiss (1990), who while approaching the subject from quite different research perspectives, agree on the need for more contextualization). At the same time, such an approach reflects movement in the field itself toward research on legal ideologies, the meanings actors ascribe to their activities, the contexts of dispute resolution, and interpretive methodologies. While this enrichment of actor-oriented perspectives has been an important development for studies of courts over time, it further underscores the need for theory to guide data collection. Researchers who pursue disaggregation and contextualization of litigation must remember that these research strategies may lead to greater detail but not necessarily to better understanding. The accumulation of detail provides closer views of actors and behavior, but it makes it more difficult to find threads of meaning or causal links of significance for such important units of analysis as the state, a court or a community, family or corporation. Theory can help distinguish useful from superfluous detail in the search for coherent explanations.

Drawing on essays in this issue and elsewhere I will describe theory that appears to be promising for longitudinal studies of trial courts.

\section{A. Revisiting Disputes}

Focusing on the dispute (and when appropriate-the case) will continue to be important. Further, as argued persuasively by Mather (1990), longitudinal studies of litigation have much to offer studies of dispute processing. I will not repeat her excellent survey of theoretical issues that can be addressed by this research, but I will mention the following as particularly important areas for development.

The most important, of course, is the opportunity longitudinal research on trial courts provides to study dispute processing as a true sequence of events and as a process that changes over time. Two conclusions follow. The field would learn much from studies in which particular conflicts are followed over time. These studies are needed in order to understand how particular disputes emerge, or do not emerge, from a context of social conflict and how participants choose among alternatives for action. The longitudinal perspective might be of relatively short duration, even focusing on the life history of particular disputes (see, e.g., Yngvesson, 1988), or of relatively long duration (compare Wollschläger, 1990), but in either case the investigator should be sensitive to the relationship between social conflict, a context for action, and disputes, which are particular manifestations of conflict (Kidder, 1980-81).

Second, Galanter's "case congregations" is a unit of analysis that is far superior to the case-type or dispute-type unit of analysis used in most longitudinal studies. The case congregation is defined 
by the social construction of disputes or cases rather than by their doctrinal or formal characteristics. Further, the concept incorporates the idea that the social construction of disputes or cases changes over time. To Galanter's list of endogenous factors that affect the social construction of a case congregation we should now add the following, as suggested by research reported in this issue that underscores the importance of the court's role in litigation: the court's role in maintaining the legitimacy of the state, the tension between professional and managerial roles of judges, and the political pressures transmitted to courts through dependence on the executive branch of government for resources, prosecutorial policy and statutory rights.

Notwithstanding the fact that most would consider Galanter's (1974) description of the litigation advantages of "haves" over "have nots" among the most fundamental in the law and society field, longitudinal research has often failed to make adequate distinctions among litigants, ignoring in particular the influence of organizations or the government-typical "haves" who dominate many areas of law or litigation. As I have explained, longitudinal research provides an opportunity to identify the frequency of participation by particular classes of litigants, the cumulative effects of repeated contacts with the legal system on "repeat players" or "haves," and the long-run effects that repeat players have on other actors.

\section{B. The Context of Litigation}

Although many insights have been gained through case studies of courts that trace subtle lines of influence and connection between courts and communities, there is room for more systematic development of theory about the influence of particular characteristics of communities. As Bourdieu (1977) recognized in his argument for the importance of adopting an actor-oriented perspective, there are relatively fixed social structures that constrain the behavior of the individual actor. Yet, relatively little longitudinal research has explored the effects of family, neighborhoods, or community, or the influence of class, religion or ethnic groups on disputing or litigating (with some wonderful exceptions, e.g., Greenhouse, 1986; Upham, 1987).

Culture (and its localized manifestations-legal culture, dispute culture, professional culture, etc.) is often mentioned, but poorly theorized, in longitudinal research as a potential explanation for change. Culture is manifested in preferences for particular social practices where alternatives exist. To understand such preferences longitudinal studies must incorporate enough knowledge about the historical context of trial courts to identify the alternatives available to contemporary actors and to explain the preference for particular choices in dispute resolution or litigation. 
In an essay in which he argues that culture, namely, popular expectations of noncompensation, underlay the limitation of tort liability prior to the early twentieth century, Friedman (1987) illustrates how research on the influence of culture can be undertaken. He shows that systematic examination of parallel institutional developments (in litigation, the insurance industry, medical treatment of industrial accidents, corporate management, and the legal profession) permits inferences about the assumptions of everyday citizens that underlie the differences between late nineteenth-century and contemporary twentieth-century preferences for types of risk management. Friedman's recreation of the context in which risk was experienced was clearly necessary in order to infer that a culture with particular preferences or expectations existed, and that that culture may be linked to compensation seeking through the tort system, receptivity to expansion of tort liability by courts, and awards of larger amounts of money by juries, all of which typify post-nineteenth-century changes in the U.S. system of tort liability. Thus, incorporation of culture into longitudinal studies of trial courts in a way that will permit accurate conclusions about its content and role in change-in a way that permits development of theory-will require research that penetrates even more deeply into the context of litigation in order to understand the choices made by those whose actions are being studied.

\section{Lawyers}

One of the most surprising oversights in longitudinal trial court research (and more generally dispute resolution research) has been systematic study of the role of lawyers and the legal profession. Lawyers constitute a resource for litigants and exert a significant influence over the social construction and transformation of disputes. Access to justice issues have historically focused on the availability of lawyers for underserved classes of potential clients, such as the poor. Determining what lawyers are available to which potential disputants and how the contacts are made is an important issue in its own right as well as an important factor in explaining patterns of litigation in trial courts over time (compare Galanter, 1974).

Reiss (1990) noted the need to understand better how clients and lawyers negotiate meanings and strategies of dispute resolution, and these interactions have implications for trial courts. The business of trial courts first passes through the hands of lawyers who must negotiate with clients and with other legal professionals about what to do next. In turn, lawyers interpret trial court behavior for clients and, more broadly, the public, affecting their perceptions of disputes and dispute resolution.

Lawyers, of course, not only have a vital influence on dispute resolution and litigation, they are repeat players in their own 
right, who may have a large stake in the outcome and whose interests differ from those of disputants or litigants. Thus, their influence over the social construction and transformation of disputes reflects not only litigants' ability to purchase lawyers' services but also the general ideology, training, and needs of the profession itself. Longitudinal studies of trial courts offer a starting point to examine the influence of changes in the organization of law practice and even the influence of lawyer training. In this respect, patterns in the handling of routine cases will be more revealing. Patterns of case filing, settlement, litigation or use of particular legal strategies, when fully explored, may be usefully understood as having been influenced by the goals, needs, or rhythms of law practice (Gordon, 1984a; Munger, 1987a).

\section{Trial Courts as Complex Organizations}

In paying greater attention to the context of cases or disputes and to the orientation of actors, longitudinal trial court research must not overlook the importance of studying disputing, litigation, and trial courts from the perspective of other levels of social organization. The dispute centeredness of much of the existing longitudinal research has drawn both quantitative and qualitative research in the field toward theories that explain disputing or litigating from the perspective of the individual litigant (see especially Felstiner, Abel, and Sarat, 1980-81; compare Sanders, 1990). As a result other perspectives or units of analysis have been ignored.

The prevalence of the dispute-centered approach has led to an important theoretical omission, the organization of the courts themselves and the differences among courts (Seron, 1990; Daniels, 1990; Clark, 1990; Ietswaart, 1990; and compare Harrington and Merry, 1988). Courts are not a constant in patterns of disputing and dispute resolution but are continuously interacting with lawyers and litigants, constructing interpretations of disputes, and changing internally in ways that affect both of these processes (Seron, 1990). As Jacob has maintained for some time, more emphasis on the study of courts as organizations is long overdue (1983a, 1983b). Longitudinal research has only recently begun to consider trial courts in light of the theory of organizations, for example, by examining the effects of their formal and informal organizational structure on what they do or by examining the activity of litigants, judges, prosecutors, attorneys, juries, court clerks; or other court officials from the perspective of their roles in a complex organization (Seron, 1990; Padgett, 1990). ${ }^{7}$

7 In some obvious ways the "gap" or "legalist" paradigm of law and social change still poses important empirical questions that must not be overlooked as we move toward a broader, more inclusive understanding of law and change. First, the primary question posed by the legalist perspective, namely, what are the symbolic and instrumental effects (Lempert, 1966) of decisions 
Not only must the changing internal structure and processes of trial courts be better understood in longitudinal research, but interactions between courts and their environments should be understood as self-interested. No published longitudinal study that I know of considers the relationship of trial courts to alternative forms of dispute resolution or how the emergence of rivals to courts might change the behavior of the courts (and further what effects those changes may have on the rivals) (but see Tanase, 1990).

Although a number of essays here warn of pitfalls of comparative research, comparisons among courts will be useful and revealing, particularly where the courts share a common legal culture and political system. Padgett's exploration (1990) of the influence of court caseload, political environment, and judicial background on plea bargaining in various federal district courts is a brilliant example of how comparative research may illuminate historical processes we cannot observe but which we can reconstruct from the variations in conditions for litigation produced by differences between courts. Many state trial court studies have involved more than one state trial court, and yet, with the exception of Daniels's essay here, different trial courts are treated as a constant having no effect on the patterns of litigation. Such an assumption seems unwarranted, and invites even closer examination of these data.

\section{E. Doctrine and Politics: Trial Courts as the State}

Longitudinal research can help to develop another perspective, that of trial courts as part of the state. Trial courts are necessarily tied to the political system of the society. For example, they have always depended on resources provided by other units of government, been influenced by the politics of legislation and judicial selection, and been affected by the political and administrative priorities of state prosecutors as well as by those of other state agencies responsible for the creation and administration of state policies that may be challenged or enforced through the courts. In

and other trial court actions, is not uninteresting or unimportant. Second, even if the answer is that these effects are small or irrelevant to the role played by law and by trial courts, or conversely, marginal to the frame of reference of some participants in conflict or dispute resolution outside of courts, the theory that they do have an effect strongly influences the behavior of many of the actors in settings studied by longitudinal trial court research. Indeed, the paradigm of "intentional" causation, in which an actor is influenced by the anticipated effects (Elster, 1985) is often a more accurate description of the relationship between law and social action than a "functional" causation paradigm in which an actor is said to influenced by the effects of action through a further feedback effect. Thus, what has been called a "gap research" paradigm may be pursued with other objectives in mind, for example, with the objective of examining beliefs about the legal system that continue to make the goal of effectiveness central to the maintenance of the behavior of trial courts and other legal institutions. 
addition, courts are constrained by the major function they perform for the state-legitimation (compare Scheingold, 1974). Prior research has overlooked the important connections that the courts provide between community and the state by legitimating and distributing power in response to political processes taking place within (Heydebrand, 1990) as well as outside the state (see Handler, 1978; Burstein and Monaghan, 1986). In examining each of these aspects of the embedding of trial courts in the state, investigators may find useful Erik Monkkonen's insight (1990) that the American State has its federal, state, and local moments, each with its own political process, and that it may be the political economy of the local state that most influences trial court behavior.

Finally, trial courts provide a record of changes within the legal system itself, including the evolution of causes of action, of court procedures, and of professional roles. The role of formal legal process is of great importance to the state and often evolves as accommodation by courts to changes as experienced and perceived at the trial court level. Thus, the evolution of the formal legal system reflects the interests of the state, judges' interpretations of the law and of their professional role, and the changes in courts created by the conditions under which they operated. In turn, these changes in the operating definitions of appropriate uses of state power have an impact on the work of courts and the conflicts that are brought before them. Longitudinal research on the interaction of doctrinal change and the behavior of trial courts and litigants is an important emerging area of research (Peterson and Priest 1982; Green, 1985; Burstein and Monaghan, 1986; Eisenberg and Schwab, 1987; Schwab and Eisenberg, 1988). Other opportunities exist for exploring the internal organization of state power and its effects. For example, many of the North American longitudinal trial court studies have encompassed the period in the late nineteenth and early twentieth centuries in which administrative law emerged, first through the use of common law writs to review the actions of government officials, and later as an exercise of statutory jurisdiction. The parallel evolution of administrative law and the administrative capacity of the state is an important chapter in the evolution of U.S. law, but it is also important in the evolution of the economy and the American state. In both contexts, by exploring trial courts in greater depth longitudinal research will add to our understanding of motivations for, resistance to, and the structure of responses of courts and the state to the shifting nature of political and economic conflict. 


\section{LIMITS IMPOSED BY RESEARCH METHODOLOGY}

If the important characteristics of longitudinal research on trial courts are its focus on change and its emphasis on closer examination of process, what, then, are the implications of these characteristics for the methods employed by this research?

\section{A. Rates}

Many criticisms of longitudinal trial court research have attacked the methods used to construct litigation rates (see Munger, 1988; Lempert, 1978; Sanders, 1990; Reiss, 1990). These criticisms seem sound. The present state of research still leaves much work for those who wish to employ quantitative measures. But the improvement of measures creates greater demands for data. For example, distinguishing between rates of incidence and those of prevalence, as forcefully argued by Reiss, requires that data on litigation, or any other aspect of disputing or litigating, reveal the identity of the party with sufficient clarity that we can determine how often particular parties appear. Further, disaggregating types of cases requires that the researcher bridge differences in official reports, or better, create appropriate categories for cases based on a content identified as relevant by theory or by sociologically (and cross-jurisdictionally) meaningful categories of behavior. But these problems may be relatively simple when compared with the task of constructing rates that properly reflect the effects of the intermediate processes of litigation or dispute resolution, for doing so means finding a base that can measure or stand for underlying causes. Thus, while sloppy practices in construction of rates may no longer be acceptable, given the extensive criticism offered to date, they may be extremely difficult to remedy due to the unavailability of information about underlying sources or causes of litigation.

\section{B. Models}

Fewer critics have focused on the unique problems of modeling processes of conflict, conflict resolution, or litigation over time. Modeling of causal relationships presents fewer problems if it is assumed that causal processes in the past are the same as those in the present (or at other times studied). But we know that moments in the past may be culturally different from those at or nearer the present and that the social organization of conflict and litigation may have quite different causes at different times. It is for this reason that Reiss (1990) argues that research on the past should be conducted as if it were being conducted in the present, as if we do not know the real outcomes of social processes and are thus forced to learn enough about then-contemporary culture and social organization to make a reasonable prediction about the direction of change on the basis of prechange information alone. For 
example, reasonable arguments constructed in the 1890 about the evolution of the process of compensating for industrial injuries might have called attention to very different aspects of society and social change than arguments about that time constructed by someone living today, because arguments constructed today would take for granted the causal forces that may appear from our present vantage point to have determined the changes and ignore others that appeared significant in 1890s and influenced the behavior of those who believed they were significant (see Friedman, 1985, 1987; Reiss, 1990).

Cultural differences between pasts or between past and present are not, however, the entire extent of the modeling problems. In addition, longitudinal research on trial courts must solve a problem in modeling causation familiar to historians, namely, that the flow of events in history may be the product of unique, not continuing, or repeating, processes and that a series of events occurring in the past may change the conditions under which similar events subsequently occur (Stinchcombe, 1968). ${ }^{8}$ To date there has been limited effort to take account of such "period effects" in longitudinal research on courts, though there are examples of excellent efforts to do so in this Special Issue (e.g., Padgett, 1990). Galanter (1990) provides an elegant example of an attempt to account for period effects in explaining litigation patterns. He describes how litigation of a sequence of similar cases over time changes the conditions under which later cases of a similar type are brought, thus causing changes not only in the pattern of litigation but also in the way external factors (e.g., accidents, debts, crimes) influence the pattern. In longitudinal research more generally, each change in court structure, law, or legal culture may be viewed in a similar way-as a unique event that may change how litigation or court processes are conducted for all future cases. Models that can account for the effects of such unique events are obviously more complex than models that assume that the patterns of causation explaining litigation remain the same over time (see Cooter and Rubinfeld, 1990). Yet, such complexities will have to be carefully considered in order to create models that explain patterns of change over any significant period of time.

\section{Data and Databases}

Richer contextualization, new theories, more precise measurement and analysis, and better modeling will require greater efforts to collect data. In conducting new research more effort will have to be expended to gather data that capture more detail. Greater

8 I am indebted to Mayer Zald for this observation on the importance of historical models of change and the frequent misapplication of ahistorical causal models in longitudinal research. The comments were made at the Conference on Longitudinal Research on Trial Courts at SUNY Buffalo, August 1987. 
economy will have to be exercised, particularly if the collection of dense contextual data is combined with the collection of docket data. More attention to theory in advance of data collection will, of course, produce economy of design and data collection, but given the rising costs of data collection, it is also important to think about preserving and sharing data.

Data sharing is always a good idea, if less widely practiced than advocated. Yet it has problems that ought to emphasized with an example. Before these essays were solicited, I had thoughts of gathering existing longitudinal trial court data sets and arranging them in the same format so that comparisons could be made and critiqued more easily. The attempt was thoroughly discouraging. Data collection appeared to be incomplete in some cases; that is, the original design was not completed and only partial sets of data were collected. Next, many longitudinal data sets were incompletely or poorly documented. Finally, data sets that had drawn their inspiration from the same source, and reputedly shared a common or similar design, were in fact so dissimilar that it was impossible to identify case classifications as common as tort or property in a similar way in purportedly similar studies.

My conclusions from this failed attempt to create a database from existing studies are both substantive and critical. First, the research methods for carrying out and documenting research designs used by all of us have often been less than ideal, rendering data unusable by others. Second, and more importantly, the difficulties of creating common categories for caseload analysis even across North American jurisdictions confirm arguments made in these essays about the importance of local legal culture. Differences in the local meaning of legal action should be anticipated and, if possible, documented. Ideally, the differences might be systematically documented and examined by collecting data other than official records, although in retrospective research this may not be possible. Third, and equally important, investigators who have quite similar perspectives on courts and change and who have addressed a similar issue (e.g., the impact of rapid economic expansion on litigation) have framed what purports to be "the issue" in significantly different ways, and have thus been led to collect different data or categorize data in different ways. The reason for some differences is in part that insights of different investigators have led in different directions and in part, no doubt, a result of pressures to make an original contribution. At the same time, the lack of careful attention to how others have examined the same question has made it difficult for results to be compared. Fourth, and more generally, it seems unlikely that investigators with substantially different interests or perceptions of processes of dispute resolution litigation could agree on data that would satisfactorily meet the needs of each.

Notwithstanding this discouraging experience, database con- 
struction and data sharing may make an important contribution to longitudinal trial court research. The great costs of longitudinal research make it worth contemplating how each particular project might be made as useful as possible to other investigators (compare Fienberg, Martin, and Straff, 1985)..$^{9}$ The goal for the individual investigator might be to gather data that will allow comparison with, and interpretation in light of, relevant work by others who share an interest in the same questions. The investigator also bears the responsibility to attempt to contextualize the records so that other understandings of actions or events occurring inside and outside of the court (e.g., a dispute) can be utilized and distinguished from the official record of the events (e.g., Clark, 1990; see Ietswaart, 1990). Remaining sensitive to the problems of uniqueness and self-reference inherent in official documents and attempting to offset them in the initial research design will go a long way toward making data more useful to colleagues.

Beyond such self-imposed collegiality, the pressure to economize will urge the creation of data bases that may be shared as well as compared.10 Collaborative, long-term data-collection projects exist in many other fields of study. While much that has been said in this Special Issue argues against the possibility of creating a set of standardized conceptual categories for longitudinal research, the usefulness of data on courts may be increased by including from the outset contextual data from sources other than official records (cf. Ietswaart, 1990) that permit users to avoid assumptions about the constancy of the meaning attached to formal processes and official categories for behavior. Nevertheless, creating a database for use by a large number of investigators will involve choices of perspective, concept definition, and theory. These choices should be sensitive to the need to link future research to existing work and to the importance of comparing and contrasting alternative conceptualizations of processes and events relevant to courts and change. Such decisions about the investment of resources are of concern to all interested in law and society research, and should be informed by a broad range of interests and views on their substance and the methods of the research.

What part should collection of docket data play in the construction of databases? Many of the conceptual and methodological problems discussed in this issue have arisen from the misuse of docket data. Notwithstanding these problems, longitudinal research on courts may continue to depend in part on docket data.

9 This report by the Committee on National Statistics of the National Academy of Sciences addresses the need for and technical aspects of data sharing as well as the benefits for a discipline and its policy applications. I am also concerned, as this report is not, about the problems and limits of attempting to specify theoretically substantive goals for a data collection as a matter of public policy.

10 These may usefully be thought of as alternative models of collaboration. See below. 
These data will be useful to investigators interested in conflict resolution, disputing, the courts, lawyers, the state, and many other significant areas of study. As Lempert suggests (1990), much useful research might simply extend the focus on the formal context of litigation in particular directions, as sources permit, with each study drawing on a common core of data derived from official sources and incorporating its categories-dockets, budgets, and administrative and legislative records. We have recognized that such information is not self-explanatory or "objective," but that does not make it less central to many questions about courts and social change. Thus, docket data might continue to comprise one important kind of information included in a database that would be of interest to many investigators, particularly investigators engaged in retrospective research. ${ }^{11}$

For the foregoing reasons, longitudinal research on trial courts can be a collaborative effort. Either of two models may be adopted. First, individual investigators can make a conscientious effort to construct parallel and interlocking research projects providing related, yet alternative, perspectives on common issues. Second, databases may be created for general use. In either case, it will be wise to remember that there is no agreement about core issues for research, though there is widespread interest in many of the particular questions discussed here. Yet there can be agreement about the value of some types of data, in particular data about the courts themselves. I have argued for the importance of making data useful to as many users as possible. To further this effort, I have stressed the particular importance of gathering infor-

11 What data should be included in a particular database for longitudinal study of trial courts seems a less difficult problem than the more important issue of what data are required to answer particular questions (see below). For retrospective research the options for data collection will be limited in most cases by the nature of the surviving court records and the likelihood that other types of information will be unavailable. These limitations make specification of "core" data easier by default but will make theoretically driven research more difficult because of the lack of information about theoretically significant units of analysis or processes. A retrospective study of trial courts employing docket data should attempt to include the basic information that exists in most official records together with usually available supplementary information that will render the docket data useful to a broad range of perspectives and theories. For example, the investigator should gather information about the number and types of cases, types of litigants, presence of lawyers, intermediate processing (such as jury trial), and formal disposition of cases. The investigator should also include basic data about the court structure and personnel, e.g., numbers and backgrounds of judges if available, number and types of other court personnel, and details of the court's jurisdiction, organization, and control by other governmental bodies. Many existing docket studies have not systematically gathered these data, even though the data were available. Gathering such data does not guarantee comparability or usefulness for all research purposes, of course, since there are no standardized categories or measures of court activity. These data, however, recorded in the terms and categories created by the courts, are directly relevant for research on the behavior of the courts themselves and so provide one important starting point for other types of data collection about disputes, cases or litigants. 
mation that permits contextualizing official records as a first step toward linking research addressing different questions and examining trial courts in different times and places.

\section{Prospective and Retrospective Research Designs}

To this point I have discussed rates, models, and data as if we might freely choose the best combination, subject only to funding limitations. A major reason for the gaps in the design of previous research, as well as for my discovery that projects that are similar in design often employ uniquely operationalized concepts, is that retrospective research must make do with available, often severely limited, data. There are often no supplementary sources to help explain or contextualize the official record of cases. The evidence drawn from official records of cases is thus "thin" (Krislov, 1983) by comparison with data that might be gathered about current disputes or court cases. Notwithstanding this limit, historical or retrospective research is important because it extends the range of available examples of human behavior over many years, where the alternative would be to begin collecting similar information now and wait years, or centuries, for it to accumulate.

A first lesson to draw from the difficulties encountered with historical or archival data is that research designs should be appropriate to the available data. This means that some kinds of questions cannot be answered adequately using historical data. For example, as the comments of several authors here make clear, conclusions drawn about disputes or disputing based on docket data alone will have many weaknesses, although such conclusions have been routinely drawn in existing docket studies. Where additional historical data on context are available, the design may be broadened to include disputing processes occurring wholly within the community outside the courts, legal culture, professionalization of court personnel, and many other aspects of the role of law inaccessible from docket data alone. Contextualization available at one point in time may permit richer interpretation of "thin" data over a broader time range by revealing a process whose existence may be tracked, if not examined directly, through docket data. It may be the case, for example, that a contextual study of tort litigation that occurred at some particular point in the past may explain low rates of tort litigation. While the contextual study may be possible for only a few years, an explanation for the continuation of low tort litigation rates over a longer period of time may be extrapolated in this way (see Lempert, 1990).

We may simply not be able to examine some hypotheses using the available historical data, and we should therefore consider the alternative, prospective longitudinal research. While prospective longitudinal research requires waiting for data to accumulate, research on some issues will demand this approach. Data sets cre- 
ated prospectively should differ in at least one important respect from those created from historical and archival data: the information collected can be, and should be, conceptually grounded and not limited to the contents of official records. Thus, for example, the key unit in a prospective longitudinal trial court study need no longer typically be the case, as defined by the court system and described in a single data source-the case file. Rather, the researcher might seek information directly describing the set of actions-potentially including formal acts by officials or courts-that constitute the process the researcher is interested in (Ietswaart, 1990). Guiding and justifying choices among the many alternative units of analysis available in prospective research will be the role of theory. Prospective creation of data sets for longitudinal study of trial courts may be a valuable undertaking for the field.

\section{THEORY AND POLITICS}

I view theory as a necessary part of longitudinal research on trial courts. Research will be advanced by using theory to stimulate alternative insights and to develop a more precise focus for inquiry, research design, and data analysis. At the same time, it should be clearly understood what I am not saying about theory. Theory need be neither value free nor universal. Its importance lies elsewhere. Theory is an attempt to formulate our understandings of the world as precisely as possible, understandings that are guided by values and are always incomplete and provisional explanations whose utility may be altered through additional experience with a changing world or which may be superseded at any moment by changing our minds about which questions ought to be answered.

The selection of a theory or starting point for research is not only of critical significance to the individual investigator, it is also of significance for the field of research (Abel, 1980). ${ }^{12}$ The field, viewed as a whole, has spoken to some issues but ignored others. As I stated in my introduction, longitudinal studies of trial courts are fundamentally about change, about resisting change, about the evolution of conflict and difference, and about competition for power to control conflict and difference. Initially, the field chose to address these issues from a very limited perspective. Now, the issues are driving researchers to develop the field beyond its original boundaries.

The energy in the field was derived first from an interest in demonstrating that trial courts mirrored social change, litigation reflecting both the interests of those affected most by social

12 As one participant remarked at the SUNY-Buffalo conference, "The question of what question to ask is the most fundamental, almost political question." This comment was made still more meaningful by the one which preceded it, in which the same participant observed that funds for research are limited. 
change and the instrumental role of law in social change. More recently, interest has grown in the constitutive role of law, law viewed as embedded in a complex set of institutions and behaviors that constitute stability or change. In the constitutive view, legal institutions give meaning to social action, not only by defining rights but by contributing to the meaning of other, often empowering, elements of society, for example, difference-class, gender, and race-and by helping to define important goals or desirable procedures for the exercise of power both within and outside of formal legal institutions. Starting points for research based on this constitutive view of legal institutions may, of course, lie wholly outside formal legal organization and may consider trial courts as of minimal importance.

The attraction of examining the constitutive role of law in social change is that it represents an alternative to "legal centrism," capturing valuable insights about the independence of social organization from particular legal institutions and the competition between law and other forms of dispute resolution (see Griffiths, 1986; Engel, 1990). But in pursuing this view, one must not make the mistake of underestimating the constitutive role of the most powerful actor in many societies. Even though its role in certain instances may be a contested one, the state circumscribes the roles played by other actors in resolving conflict. Conflict over the distribution of power is ultimately conflict about control of the state. Thus, while we may recognize that a view of dispute resolution that considers only the formal activity of courts is too narrowly centered in the legal institutions of the state, it is highly important to attempt to understand why and how the state makes claims to power and to authoritative dispute resolution. Behind these claims lies the political as well as the self-interested role of the state. ${ }^{13}$ Thus, to fully understand the constitutive roles of law, continuing thought and research are required to examine the state's role in conflict, including its role in selecting among competing forms of conflict resolution, its role in the distribution of power generally and among potential litigants in particular, and how the state both exercises its power and makes effective claims to the power it exercises. These are among the most significant issues for another generation of longitudinal trial court studies.

13 With respect to the political functions of courts, at the conference Lawrence Friedman observed that North Americans think of courts as part of their "government" while many other cultures, notably European, think in terms of a "state." "Government" and "state" have quite distinct connotations. Thinking of courts as part of government suggests that they are like administrative offices of government and exercise what is fundamentally perceived as nonpolitical authority. The concept of the state is more suggestive of power relations and the political uses of power, and societies with different political cultures are quite comfortable with the view that courts are a part of such a state. This difference in political cultures has, quite clearly, also influenced the approaches to courts taken by North American social science. 



\section{REFERENCES}

ABEL, Richard L. (1982) "The Contradictions of Informal Justice," in Richard L. Abel (ed.), The Politics of Informal Justice, Vol. 1 New York: Academic Press.

(1980) "Redirecting the Social Studies of Law," 14 Law \& Society Review 80 .

(1973) "A Comparative Theory of Dispute Institutions in Society," 8 Law \& Society Review 217.

ABROMOWITZ, David (1982) "Past Claimant as Future Victim: Commercial Retaliation and the Erosion of Court Access," 17 Harvard Civil RightsCivil Liberties Law Review 209.

ALEXANDER, Jeffrey C. (1984) "Structural Analysis: Some Notes on Its History and Prospects," 25 Sociological Quarterly 5.

ALEXANDER, Jeffrey C., and Bernhard GIESEN (1987) "From Reduction to Linkage: The Long View of the Micro-Macro Debate," in J. C. Alexander, B. Giesen, R. Munch, and N. J. Smelser (eds.), The Micro-Macro Link. Berkeley: University of California Press.

ALFORD, Robert R., and Roger FRIEDLAND (1985) Powers of Theory: Capitalism, the State and Democracy. Cambridge: Cambridge University Press.

ALLEN, Michael (1987) "Cleaning House: U.S. Companies Pay Increasing Attention to Destroying Files," Wall Street Journal, 2 September, p. 1. .

ALSCHULER, Albert W. (1979) "Plea Bargaining and Its History," 79 Columbia Law Review 1.

_ (1976) "The Trial Judge's Role in Plea Bargaining," 76 Columbia Law Review 1059.

ALTERNATIVES to the High Cost of Litigation (1988), "The Manville Asbestos Trust," 6 Alternatives to the High Cost of Litigation 1.

AMENTA, Edwin, Elizabeth S. CLEMENS, Jefren OLSEN, Sunita PARIKH, and Theda SKOCPOL (1987) The Political Origins of Unemployment Insurance in Five American States. Studies in American Political Development: An Annual, Vol. 2. New Haven, CT: Yale University Press.

AMERICAN LAW INSTITUTE (1934) A Study of the Business of the Federal Courts, Part I: Criminal Cases. Philadelphia: American Law Institute.

ARON, Raymond (1967) Main Currents in Sociological Thought. Vol. 2. Garden City, NY: Doubleday.

AUBERBACH, Jerold S. (1976) Unequal Justice. New York: Oxford University Press.

AXELROD, Robert (1970) Conflict of Interest. Chicago: Markham Press.

AYERS, Edward L. (1984) Vengeance and Justice: Crime and Punishment in the Nineteenth Century American South. New York: Oxford University Press.

BALBUS, Isaac D. (1973) The Dialectics of Legal Repression: Black Rebels Before the American Criminal Courts. New York: Russell Sage Foundation.

BARNETT, Harold C. (1981) "Corporate Capitalism, Corporate Crime," 27 Crime and Delinquency 4.

BAUM, Lawrence, Sheldon GOLDMAN, and Austin SARAT (1981-82) "Research Note: The Evolution of Litigation in the Federal Courts of Appeals, 1895-1975," 16 Law \& Society Review 291.

BAUUMGARTNER, Mary Patricia (1988) The Moral Order of a Suburb. New York: Oxford University Press.

- (1984) "Social Control in Suburbia," in Donald Black (ed.) Toward a General Theory of Social Control, Vol. 2. Orlando, FL: Academic Press.

BEAN, Ed (1986) "After 137 People Died in Its Texas Jet Crash, Delta Helped Families," Wall Street Journal, 7 November, p. 1.

BELKIN, Lisa (1987) "Roles and Dollars at Stake in Soap-Opera Cliffhangers," New York Times, 28 April, p. C-18.

Prepared with the assistance of James Snashall.

LAW \& SOCIETY REVIEW, Volume 24, Number 2 (1990) 
BELL, C., and C. PRICE (1982) "Running for Judge in California: Superior Court Elections, 1978-1980," 6 California Data Brief 1.

BELLUCK, Pam (1985) "Tenants Cry Foul as Screening Companies Help Landlords Spot 'Problem' Applicants," Wall Street Journal, 27 December, p. 11.

BENDIX, Reinhardt, and Guenther ROTH (1971) Scholarship and Partisanship: Essays on Max Weber. Berkeley: University of California Press.

BERG, GERARD P. VAN DEN (1985) The Soviet System of Justice: Figures and Policy. Boston: Martinus Nijhoff.

BERGSTROM, Randolph E. (1988) "Courting Danger: Injury Suits in New York City, 1870-1910." Presented at the annual meetings of the Law \& Society Association, Vail, Colorado.

BERK, Richard A., Sheldon L. MESSINGER, David RAUMA, \& John E. BERECOCHEA (1983) "Prisons as Self-regulating Systems: A Comparison of Historical Patterns in California for Male and Female Offenders," 17 Law \& Society Review 547.

BEST, Arthur, and Allan R. ANDREASEN (1977) "Consumer Responses to Unsatisfactory Purchases: A Survey of Perceiving Defects, Voicing Complaints and Obtaining Redress," 11 Law \& Society Review 701.

BIDERMAN, A. D., and A. J. REISS, Jr. (1967) "On Exploring the 'Dark Figure' of Crime," 374 The Annals 1.

BLACK, Donald J. (1980) The Manners and Customs of the Police. New York: Academic Press.

- (1976) The Behavior of Law. New York: Academic Press.

- (1973) "The Mobilization of Law," 2 Journal of Legal Studies 125. 1087

- (1970) "Production of Crime Rates," 35 American Sociological Review 733.

BLANKENBURG, Erhard (ed.) (1989) Prozessflut? Studien zur Prozesstätigkeit europäischer Gerichte in historischen Zeitreihen und im Rechtsvergleich. Cologne: Bundesanzeiger.

(1975) "Studying the Frequency of Civil Litigation in Germany," 9 Law \& Society Review 307.

BLAU, Peter (1964) Exchange and Power in Social Life. New York: Wiley.

BLEGVAD, Britt-Mari (1990) "Commercial Relations, Contract and Litigation in Denmark: A Discussion of Macaulay's Theories," 24 Law \& Society Review 397.

- (1987) "Rationalitet og irrationalitet som basis for beslutning og handling $i$ organisation," in Britt-Mari Blegvad and Colin Finn (eds.), Virksomheden Mellem Okonomi og jura-om retsokonomi og styring. Copenhagen: Samfundslitteratur.

(1986) "Report to the Danish Research Council with Three Case Studies." Unpublished report of the Institute of Organization and Industrial Sociology, Copenhagen, Denmark.

- (1983) "Sweeping Little Injustices Under the Carpet: A Case Study of Consumer Dispute Treatment and Norm Generation," Working Paper 1983-8 of the Dispute Processing Research Program, Madison, Wisconsin.

BLEGVAD, Britt-Mari, P. O. BOLDING, and Ole LANDO, in cooperation with Kirsten GAMST-NIELSEN (1973) Arbitration as a Means of Solving Conflicts. Copenhagen: New Social Science Monographs.

BLEGVAD, Britt-Mari, and Nell RASMUSSEN (1975) "The Lay Judges of the Danish Maritime and Commercial Court." Research Report of the Institute of Organization and Industrial Sociology, Copenhagen, Denmark.

BLEGVAD, Britt-Mari, Valdemar THOMSEN, and Annegrete WULFF (1981) Forbrugerklageorganer $i$ organisationssociologisk perspektiv, Vols. 1 and 2. Research Report of the Institute of Organization and Industrial Sociology, Copenhagen, Denmark.

BLEGVAD, Britt-Mari, and Annegrete WULFF (1989) "Prozessflut aller Orten? Danemark: Ein Gegenbefund und seine Ursachen," in E. Blankenburg (ed.), Prozessflut? Studien zur Prozesstätigkeit europäischer Gerichte in historischen Zeitreihen und im Rechtsvergleich. Bonn: Bundesanzeiger.

(1984) "The Alleged Litigation Explosion: Danish Data." Presented at 
the Conference on Litigation, Gummersbach, West Germany (Theodor Heuss Academie).

BLOCK, Fred (1987) Revising State Theory. Philadelphia: Temple University Press.

(1977) "The Ruling Class Does Not Rule: Notes on the Marxist Theory of State," 7 Socialist Revolution 6.

BLUM, Andrew (1990) "Law Firm Gets Involved in Tobacco Debate," National Law Journal, Mar. 19, p. 14.

BLUME, Lawrence E., and Daniel L. RUBINFELD (1982) "The Dynamics of the Legal Process," 11 Journal of Legal Studies 405.

BLUMBERG, Abraham S. (1967) Criminal Justice. Chicago: Quadrangle.

BOGUE, Allan (1963) From Prairie to Corn Belt: Farming on the Mlinois and Iowa Prairies in the Nineteenth Century. Chicago: University of Chicago Press.

BOHANNAN, Paul (1967a) "Introduction," in Paul Bohannan (ed.), Law and Warfare: Studies in the Anthropology of Conflict. New York: Natural History Press.

- (1967b) The Differing Realms of the Law," in Paul Bohannan (ed.), Law and Warfare: Studies in the Anthropology of Conflict. New York: Natural History Press.

BONAFÉ-SCHMITT, Jean-Pierre (1986) "Les justices du quotidient." Rapport de Recherche, document GLYSI no. $1 / 86$.

BOURDIEU, Pierre (1987) "The Force of Law: Toward Sociology of the Juridical Field," 38 Hastings Law Journal 201.

(1977) Outline of a Theory of Practice. Cambridge: Cambridge University Press.

BOWLES, A. (1982) Law and the Economy. Oxford: Oxfordshire Press.

BOYUM, Keith O. (1983) "The Etiology of Claims: Sketches for a Theoretical Mapping of the Claim-Definition Process," in Keith O. Boyum and Lynn Mather (eds.), Empirical Theories About Courts. new York: Longman.

BOYUM, Keith, and Lynn MATHER (1983) Empirical Theories About Courts. New York: Longman.

BRAEUTIGAM, Ronald, Bruce M. OWEN, and John PANZAR (1984) "An Economic Analysis of Alternative Fee Schifting Systems," 47 Law and Contemporary Problems 173.

BREYER, Stephen (1982) Regulation and Its Reform. Cambridge, MA: Harvard University Press.

BREYER, Stephen, and Richard STEWART (1985) Administrative Law and Regulatory Policy. 2d ed. Boston: Little, Brown.

BRICKEY, Stephen L., and Dan E. MILLER (1975) "Bureaucratic Due Process: An Ethnography of a Traffic Court," 22 Social Problems 688.

BRIGHAM, John (1985) "Judicial Impact upon Social Problems: A Perspective on Ideology," 9 Legal Studies Forum 47.

BRODEUR, Paul (1985) Outrageous Misconduct: The Asbestos Industry on Trial. New York: Pantheon.

BROOKS, C. W. (1978) "Litigants and Attorneys in the King's Bench and Common Pleas," in J. H. Baker (ed.), Legal Records and the Historian: Papers Presented to the Cambridge Legal History Conference. London: Royal Historical Society.

BUCKLE, L. G., and Susan R. THOMAS-BUCKLE (1982) "Doing unto Others: Disputes and Dispute Processing in an Urban American Neighborhood," in R. Tomasic and M. Feeley (eds.), Neighborhood Justice: Assessment of an Emerging Idea. New York: Longman.

BURBANK, Stephen (1982) "The Rules Enabling Act of 1934," 120 University of Pennsylvania Law Review 1015.

BURSTEIN, Paul (1987) "Race, Religion, Sex and National Origin: Barriers to Mobility in the American Labor Market, 1965-1985." Presented at the Conference on Longitudinal Research on Trial Courts, State University of New York at Buffalo.

BURSTEIN, Paul, and Kathleen MONAGHAN (1986) "Equal Employment Opportunity and the Mobilizing of Law," 20 Law \& Society Review 355.

BURGER, Warren (1970) "The State of the Judiciary: 1970," 56 American Bar Association Journal 929.

CAIN, Maureen, and Kalman KULCSAR (1981-82) "Thinking Disputes: An 
Essay on the Origins of the Dispute Industry," 16 Law \& Society Review 375.

CALAVITA, Kitty (1983) "The Demise of the Occupational Safety and Health Administration: A Case Study in Symbolic Action," 30 Social Problems 437.

CAMPBELL, Ballard C. (1980) Representative Democracy: Public Policy and Midwestern Legislatures in the Late Nineteenth Century. Cambridge, MA: Harvard University Press.

CAPPELLETTI, Mauro, and Joseph M. PERILLO (1965) Civil Procedure in Italy. The Hague: Martinus Nijhoff.

CARNOY, Martin (1984) The State and Political Theory. Princeton, NJ: Princeton University Press.

CARTER, Terry (1988) "Let 1,000 Asbestos Suits Bloom," National Law Journal, 26 December, p. 2.

CARTWRIGHT, Bliss (1975) “Conclusion: Disputes and Reported Cases," 9 Law \& Society Review 369.

CASPER, Gerhard, and Richard A. POSNER (1974) "Study of the Supreme Court's Caseload," 3 Journal of Legal Studies 339.

CERTOMA, G. Leroy (1985) The Italian Legal System. London: Butterworth.

CHAYES, Abram (1976) "The Role of the Judge in Public Law Litigation," 89 Harvard Law Review 1281.

CHERNIACK, Martin (1986) The Hawk's Nest Incident: America's Worst Industrial Disaster. New Haven, CT: Yale University Press.

CHIN, Audrey, and Mark A. PETERSON (1985) Deep Pockets, Empty Pockets? Who Wins in Cook County Jury Trials. Santa Monica, CA: Institute for Civil Justice.

CHURCH, Thomas W. (1982) Examining Local Legal Culture: Practitioner Attitudes in Four Criminal Courts. Washington, DC: National Institute of Justice.

CICOUREL, Aaron V. (1968) The Social Organization of Juvenile Justice. New York: Wiley.

CIPOLLA, Carlo M. (1976) "Introduction," in Carlo M. Cipolla (ed.), The Fontana Economic History of Europe, Vol. 3. New York: Harvester Press.

CLAGGETT, William (1986) "Walter Dean Burnham and the Dynamics of American Politics," 10 Social Science History 205.

CLARK, David S. (1990) "Civil Litigation Trends in Europe and Latin America Since 1945: The Advantage of Intra-Country Comparisons," 24 Law \& Society Review 549.

(1988) "Civil Litigation, Access to Justice, and Social Change: Research Issues in Longitudinal Court Studies," 12 Southern Ilinois University Law Journal 713.

(1981) "Adjudication to Administration: A Statistical Analysis of Federal District Courts in the Twentieth Century," 55 Southern California Law 65.

CLEARY, Edward (1984) McCormick on Evidence. 3d ed. St. Paul, MN.: West Publishing Co.

CLENDINEN, Dudley (1986) "Doctors in Georgia City Strike Back Over Suits," New York Times, 14 May, p. 1.

CLOUGH, Shephard B., and Richard T. RAPP (1975) European Economic History: The Economic Development of Western Civilization. 3d ed. New York: McGraw Hill.

COASE, Ronald (1960) "The Problem of Social Cost," 3 Journal of Law and Economics 1.

COATES, Dan, and Steven PENROD (1980-81) "Social Psychology and the Emergence of Disputes," 15 Law \& Society Review 655.

COFFEE, John C., Jr. (1987) "The Regulation of Entrepreneurial Litigation: Balancing Fairness and Efficiency in the Large Class Action," 54 University of Chicago Law Review 877.

- (1986) "Understanding the Plaintiff's Attorney: The Implications of Economic Theory for Private Enforcement of the Law Through Class and Derivative Actions," 86 Columbia Law Review 669.

COHEN, Laurie P. (1990) "Broader Suits Over Cigarettes May Be Possible," Wall Street Journal, 1 August, p. 10.

COHN, Bernard S. (1976) "Some Notes of Law and Change in Northern In- 
dia," in Paul Bohannan (ed.), Law and Warfare: Studies in the Anthropology of Conflict. New York: Natural History Press.

COLEMAN, James S. (1990) Foundations of Social Theory. Cambridge, MA: Belknap Press.

- (1987) "Microfoundations and Macrosocial Behavior," in Jeffrey C. Alexander, Bernhard Giessen, Richard Munch, and Neil Smelser (eds.), The Micro-Macro Link. Berkeley: University of California Press.

- (1986) "Social Theory, Social Research, and a Theory of Action," 91 American Journal of Sociology 1309.

COLLIER, Jane F. (1973) Law and Social Change in Zinacantan. Stanford, CA: Stanford University Press.

COMAROFF, John L., and Simon A. ROBERTS (1977) "The Invocation of Norms in Dispute Settlement," in I. Hamnett (ed.), Social Anthropology and Law. New York: Academic Press.

COMMAILLE, Jacques, Patrick FESTY, Pierre GUIBENTIF, Jean KEL LERHALS, Jean Francois PERRIN, and Louis ROUSSEL (1983) Le divorce en Europe occidentale: La loi et le nombre. Geneva: CETEL.

COMMITTEE ON STANDARDS (1975) Standards of Judicial Practices: The Complaint Procedure. Boston: Administrative Offices of the District Court.

COOK, Beverly Blair (1973) "Sentencing Behavior of Federal Judges: Draft Cases-1972," 42 University of Cincinnati Law Review 597.

COOPER, Alan (1988) "It's Over: Robins Plan Gets the Nod," National Law Journal, August 10, p. 10.

COOPER, Jeremy (1981) "Legal Service in Three Countries: A Study of the Relationship Between Policy and Practice." Ph.D. dissertation, Florence European University Institute.

COOTER, Robert (1987) "Why Litigants Disagree: Comment on Priest's 'Measuring Legal Change'," 3 Journal of Law, Economics, and Organization 227. 107.

COOTER, Robert, and KORNHAUSER, Lewis (1980) "Can Litigation Im. prove the Law Without the Help of Judges?" 9 Journal of Legal Studies 139.

COOTER, Robert, and Daniel L. RUBINFELD (1990) "Trial Courts: An Economic Perspective," 24 Law \& Society Review 533.

(1989) "The Economics of Legal Disputes and Their Resolution," 27 Journal of Economic Literature 1067.

COOTER, Robert, and Thomas UHLEN (1986) "An Economic Case for Comparative Negligence," 61 New York University Law Review 1067.

COSER, Lewis A. (1971) Masters of Sociological Thought: Ideas in Historical and Social Context. New York: Harcourt Brace Jovanovich.

CUMMINGS, Homer, and Carl McFARLAND (1937) Federal Justice: Chapters in the History of Justice and the Federal Executive. New York: Macmillan.

CURTIS, George B. (1977) "The Colonial County Court, Social Forum and Legislative Precedent, Accomack County Virginia, 1633-1636," 85 Virginia Magazine of History and Biology 274.

DAINTITH, T. C. (1988) "Contract Design and Practice in the Natural Resources Sector," 1988 European Yearbook in the Sociology of Law 193.

(1986) "The Design and Performance of Long-Term Contracts," in T. C. Daintith and G. Teubner (eds.), Contract and Organisation: Legal Analy. sis in the Light of Economic Theory. Berlin: De Gruyter.

DAM, Kenneth (1975) "Class Actions: Efficiency, Compensation, Deterrence and Conflicts of Interest," 4 Journal of Legal Studies 47.

DANIELS, Stephen (1990) "Caseload Dynamies and the Nature of Change: The Civil Business of Trial Courts in Four Illinois Counties," 24 Law \& Society Review 299.

(1988) "A Tangled Tale: Studying State Supreme Courts," 22 Law \& Society Review 833.

(1986) "Explaining Case Load Dynamics: The Use of Evolutionary Models." Presented at the Annual Meeting of the Law and Society Association, Washington, D.C. 
(1985) "Continuity and Change in Patterns of Case Handling: A Case Study of Two Rural Counties," 19 Law \& Society Review 381.

(1984) "Ladders and Bushes: The Problem of Caseloads and Studying Court Activities Over Time," 1984 American Bar Foundation Research Journal 751.

- (1982) "Civil Litigation in Illinois Trial Courts: An Exploration of Rural-Urban Differences," 4 Law and Policy Quarterly 190.

(1981) "The Trial Courts of Spoon River: Patterns and Change, 1870 to 1963." Presented at the Annual Meeting of the Law and Society Association, Amherst, MA.

(1980) "Patterns and Changes in Illinois Trial Courts." Proposal submitted to the National Science Foundation.

DANMARK STATISTIK (1971-86) "Statistisk Arbog, Danmark." Unpublished statistical series.

DANZIG, Richard, and Michael J. LOWY (1975) "Everyday Disputes and Mediation in the U.S.: A Reply to Professor Felstiner," 9 Law \& Society Review 675 .

DANZON, Patricia Munch (1983) "Contingent Fees for Personal Injury Litigation," 14 Bell Journal of Economics 213.

DAVIS, Martha (1985) "Defend Thyself: How Doctors Are Protecting Themselves from Malpractice Suits," Chicago Magazine, 149 (October).

DAVIS, Natalie Zemon (1975) "Strikes and Salvation at Lyon," in Society and Culture in Early Modern France: Eight Essays. Stanford, CA: Stanford University Press.

DENZAU, Arthur (1979) "Litigation Expenditures as Private Determinants of Judicial Decisions: A Comment," 8 Journal of Legal Studies 295.

DENZIN, Norman (1970) The Research Act: A Theoretical Introduction to Sociological Methods. Chicago: Aldine Publishing Co.

DEPARTAMIENTO ADMINISTRATIVO NACIONAL DE ESTADÍSTICA (1981-86) Colombia Estadística. Bogota: DANE.

DEVLIN, Rose Anne (1989) "Some Welfare Implications of No-Fault Automobile Insurance." Draft, University of Newfoundland.

DIAMOND, Stephen (1983) "The Death and Transfiguration of Benefit Taxation: Special Assessments in Nineteenth-Century America," 12 Journal of Legal Studies 201.

DICKINSON, John A. (1976) "L'activite judiciaire d'apres la procedure civile. Le bailliage de Falaise, 1688-1790," 84 Revue d'histoire economique et sociale 145.

DIRECCIÓN GENERAL DE ESTADÍSTICA Y CENSOS (1974-85) Annuario Estadístico de Costa Rica. San José, Costa Rica: DGEC.

DOUGHERTY, Kevin (1986) "The State-Manager Theory of the State: A Critique and Reformulation." Unpublished paper.

DOUGLAS, Jack D. (1967) The Social Meanings of Suicide. Princeton, NJ: Princeton University Press.

DUNCAN, Otis Dudley (1984) Notes on Social Measurement: Historical and Critical. New York: Russell Sage Foundation.

DUNGWORTH, Terrance (1988) Product Liability and the Business Sector: Litigation Trends in Federal Courts. Santa Monica, CA: Institute for Civil Justice.

DURKHEIM, Emile (1965) The Elementary Forms of Religious Life. New York: Free Press. lan. Press.

[1897] (1951) Suicide. A Study in Sociology. New York: Macmillan.

DWORKIN, Ronald (1980) "Is Wealth a Value?" 9 Journal of Legal Studies 191.

- (1977) "The Model of Rules," in Ronald Dworkin, Taking Rights Seriously. Cambridge, MA: Harvard University Press.

EADS, George, and Peter Reuter (1983) Designing Safer Products: Corporate Responses to Product Liability Law and Regulation. Santa Monica, CA: Institute for Civil Justice. 
EASTERBROOK, Frank H (1982) "Ways of Criticizing the Court," 95 Harvard Law Review 802.

(1984) "The Supreme Court, 1983 Term-Foreword: The Court and The Economic System," 98 Harvard Law Review 4.

EDELMAN, Murray (1988) Constructing the Political Spectacle. Chicago: University of Chicago Press.

EDWARDS, Ward, and Amos TVERSKY (eds.) (1967) Decision Making. Harmondsworth: Penguin.

EISENBERG, Theodore (1982) "Section 1983: Doctrinal Foundations and an Empirical Study," 67 Cornell Law Review 482.

EISENBERG, Theodore, and Stewart J. SCHWAB (1987) "The Reality of Constitutional Tort Litigation," 72 Cornell Law Review 64.

ELAZAR, Daniel Judah (1962) The American Partnership: Intergovernmental Co-operation in the Nineteenth-Century United States. Chicago: University of Chicago Press.

ELSTER, Jon (1985) Making Sense of Marx. Cambridge: Cambridge University Press.

EMERSON, Robert M. (1983) "Holistic Effects in Social Control Decisionmaking," 17 Law \& Society Review 425.

EMERSON, Haven (1941) Population, Births, Notifiable Diseases, and Deaths, Assembled for New York City, New York: 1866-1938. New York: DeLamar Institute of Public Health, Columbia University.

ENGEL, David M. (1990) "Litigation Across Space and Time: Courts, Conflict and Social Change," 24 Law \& Society Review 333.

- (1987) "Law, Time, and Community," 21 Law \& Society Review 605.

(1985) "Review of Empirical Theories About Courts," 9 Legal Studies Forum 101.

- (1984) "The Ovenbird's Song: Insiders, Outsiders," 18 Law \& Society Review 101.

(1980) "Legal Pluralism in an American Community: Perspectives on a Civil Trial Court," 1980 American Bar Foundation Research Journal 425. (1978) Code and Custom in a Thai Provincial Court: The Interactions of Formal and Informal Systems of Justice. Tucson: University of Arizona Press.

FALLERS, Lloyd A. (1969) Law Without Precedent: Legal Ideas in Action in the Courts of Colonial Busoga. Chicago: University of Chicago.

FEDDERS, John M., and Lauryn H. GUTTENPLAN (1980) "Documents Retention and Destruction: Practical, Legal and Ethical Considerations," 56 Notre Dame Lazoyer 5.

FEDERAL CIVIL JUDICIAL PROCEDURE AND RULES (1986) St. Paul, MN: West Publishing Co.

FEELEY, Malcolm M. (1979). The Process Is the Punishment. New York: Russell Sage Foundation.

FELSTINER, William L. F. (1975) "Avoidance as Dispute Processing: An Elaboration," 9 Law \& Society Review 695. (1974) "Influences of Social Organization on Dispute Processing," 9 Law \& Society Review 63.

FELSTINER, William L. F., Richard ABEL, and Austin SARAT (1980-81) "The Emergence and Transformation of Disputes: Naming, Blaming, Claiming ...." 15 Law \& Society Review 631.

FESTY, Patrick, and Marie-France VALETAS (1986a) Le paiement des pensions alimentaires aux femmes divorces: Rapport preliminaire. Paris: INED.

IN (1986b) "Quelques variables associés au montant et au paiement des pensions alimentaires." Unpublished paper, INED, Paris.

FIENBERG, S. E., M. E. MARTIN, and M. L. STRAFF (1985) Sharing Research Data. Washington, DC: National Research Council.

FINKELSTEIN, Michael O. (1975) "A Statistical Analysis of Guilty Plea Practices in the Federal Courts," 89 Harvard Law Review 293.

FITZGERALD, Jeffrey, and Richard DICKINS (1980-81) "Disputing in Legal and Non-legal Contexts: Some Questions for Sociologists of Law," 15 Law \& Society Review 631.

FLANAGAN, Robert J. (1987) Labor Relations and the Litigation Explosion. Washington, DC: Brookings Institution. 
FOUCAULT, Michael (1979) Discipline and Punish: The Birth of the Prison. New York: Vintage Books.

- (1973) The Order of Things: An Archaeology of the Human Sciences. New York: Vintage Books.

FRANKFURTER, Felix, and Thomas G. CORCORAN (1926) "Petty Federal Offenses and the Constitutional Guaranty of Trial by Jury," 39 Harvard Law Review 917.

FRANKFURTER, Felix, and James M. LANDIS (1927) The Business of the Supreme Court: A Study in the Federal Judicial System. New York: Macmillan.

FREIDSON, Eliot (1986) Professional Powers: A Study of the Institutionalization of Formal Knowledge. Chicago: University of Chicago Press.

FREUDENHEIM, Milt (1988) "Dalkon Shield Trust Fund Organizes," New York Times, 23 August, p. 23.

FRIEDMAN, Lawrence M. (1990a) "Opening the Time Capsule: A Progress Report on Studies of Courts Over Time," 24 Law \& Society Review 229.

- (1990b) The Republic of Choice: Law, Authority and Culture. Boston: Harvard University Press.

- (1989a) "Litigation and Its Discontents," 40 Mercer Law Review 973.

- (1989b) "Litigation and Society," 15 Annual Review of Sociology 17.

- (1987) "Civil Wrongs: Personal Injury Law in the Late 19th Century," 1987 American Bar Foundation Research Journal 351.

(1985) Total Justice. New York: Russell Sage Foundation.

- (1984) "American Legal History: Past and Present," 34 Journal of Legal Education 563.

- (1983) "Courts over Time: A Survey of Theories and Research," in K. Boyum and L. Mather (eds.), Empirical Theories about Courts. New York: Longman.

(1979) "Plea Bargaining in Historical Perspective," 13 Law \& Society Review 247.

Review (1976) "Trial Courts and Their Work in the Modern World," 4 Jahrbuch für Rechtssoziologie and Rechtstheorie 25.

(1975) "San Benito 1890: Legal Snapshot of a County," 27 Stanford Law Review 687.

L (1973) A History of American Law. New York: Simon \& Schuster.

- (1969) "Legal Culture and Social Development," 4 Law \& Society Review 29 .

- (1967) "Legal Rules and the Process of Social Change," 19 Stanford Law Review 786.

(1965) Contract Law in America: A Social and Economic Case Study. Madison: University of Wisconsin Press.

FRIEDMAN, Lawrence M., Robert R. KAGAN, Bliss CARTWRIGHT, and Stanton WHEELER (1981) "State Supreme Courts: A Century of Style and Citation," 33 Stanford Law Review 773.

FRIEDMAN, Lawrence M., and Jack LADINSKY (1967) "Social Change and the Law of Industrial Accidents," 67 Columbia Law Review 50.

FRIEDMAN, Lawrence M., and Robert PERCIVAL (1981) The Roots of Justice: Crime and Punishment in Alameda County, California, 1870-1910. Chapel Hill: University of North Carolina Press.

(1976a) "A-Tale of Two Courts: Litigation in Alameda and San Benito Counties," 10 Law \& Society Review 267.

(1976b) "Who Sues for Divorce? From Fault Through Fiction to Freedom," 5 Journal of Legal Studies 61.

FRIEDMAN, Lawrence M., and Manfred REHBINDER, (eds.) (1976) "Sociologie des Gerichtsverfahrens," 4 Jahrbuch für Rechtssoziologie und Rechtstheorie 25.

FRIENDLY, Henry (1973) Federal Jurisdiction: A General View. New York: Columbia University Press.

FRUG, Gerald E. (1980) "The City as Legal Concept," 93 Harvard Law Review 1059.

FULLER, Lon (1978) "The Forms and Limits of Adjudication," 92 Harvard Law Review 353.

- (1934) "American Legal Realism," 82 University of Pennsylvania Lawo Review 429. 
GALAMBOS, Louis (1983) "Technology, Political Economy, and Professionalization: Central Themes of the Organizational Synthesis," 57 Business History Review 471.

GALANTE, Mary Ann (1985) "Doctors, Attorneys Feud Over 'Hotlines' in California," National Law Journal, 2 December, p. 9.

GALANTER, Marc (1990) "Case Congregations and Their Careers," 24 Law \& Society Review 371.

- (1986a) "Adjudication, Litigation, and Related Phenomena," in Leon Lipson and Stanton Wheeler (eds.), Law and the Social Sciences. New York: Russell Sage Foundation.

(1986b) "The Day After the Litigation Explosion," 46 Maryland Law Review 3.

(1985a) "Lawyers' Litigation Networks." Presented to the Conference on the Frontiers of Research on Litigation, Madison.

(1985b) "Vision and Revision: A Comment on Yngvesson," 1985 Wisconsin Law Review 647.

(1983a) "Reading the Landscape of Disputes: What We Know and Don't Know (and Think We Know) About Our Allegedly Contentious and Litigious Society," 31 UCLA Law Review 4.

- (1983b) "The Radiating Effects of Courts," in Keith O. Boyum and Lynn Mather (eds.), Empirical Theories about Courts. New York: Longman.

(1979) "Legality and Its Discontents: A Preliminary Assessment of Current Theories of Legalization and Delegalization," in E. Blankenburg, E. Klausa, and H. Rottleuthner (eds.) Alternative Rechtsformen und Alternativen zum Recht. Bonn: Westdeutscher Verlag.

(1974a) "Why the 'Haves' Come Out Ahead: Speculation on the Limits of Legal Change," 9 Law \& Society Review 95.

(1974b) "Afterword: Explaining Litigation," 9 Law \& Society Review 347.

GALANTER, Marc, and Joel ROGERS (1988) "The Transformation of American Business Disputing: Some Preliminary Observations." Presented at the Annual Meeting of the Law and Society Association, Vail, CO.

GANS, Alfred W., and Paul D. RHEINGOLD (1984) [1960] "Multiple Litigation," in Louis R. Frumer and Melvin I. Friedman (eds.), Products Liabil. ity, Vol. 3A. New York: Matthew Bender.

GEERTZ, Clifford (1983) Local Knowledge: Further Essays in Interpretive Anthropology. New York: Basic Books.

GEIS, Gilbert (1967) "The Heavy Electrical Equipment Antitrust Cases of 1961," in M. Clinard and R. Quinney (eds.), Criminal Behavior Systems: $A$ Typology. New York: Holt, Rinehart \& Winston.

GERE, Edwin A. (1982) "Dillon's Rule and the Cooley Doctrine: Reflections of the Political Culture," 8 Journal of Urban History 271.

GIBBS, Jack P. (1975) Crime, Punishment and Deterrence. New York: Elsevier Scientific Publishing Co.

GIDDENS, Anthony (1984) The Constitution of Society: Outline of the Theory of Structuration. Cambridge, MA: Polity Press.

(1979) Central Problems in Social Theory: Action, Structure and Contradiction in Social Analysis. Berkeley: University of California Press. (1971) Capitalism and Modern Social Theory: An Analysis of the Writings of Marx, Durkheim, and Max Weber. Cambridge: Cambridge University Press.

GIFFORD, Donald G., and David J. NYE (1987) "Litigation Trends in Florida: Saga of a Growth State," 39 University of Florida Law Review 829.

GILES, Michael W., and Thomas D. LANCASTER (1989) "Political Transition, Social Development and Legal Mobilization in Spain," 83 American Political Science Review 817.

GIVELBER, Daniel J., William J. BOWERS, and Carolyn L. BLITCH (1984) "Tarasoff, Myth and Reality: An Empirical Study of Private Law in Action," 1984 Wisconsin Law Review 443.

GLUCKMAN, Max (1955) The Judicial Process Among the Barotse of Northern Rhodesia. Manchester: Manchester University Press.

GOLEMAN, Daniel (1987) "When Do a Therapist's Actions Cross Over the Line?" New York Times, 19 November, p. 16. 
GOODMAN, John (1978) "An Economic Theory of the Evolution of the Common Law," 7 Journal of Legal Studies 393.

GORDON, Robert (1984a) "Legal Thought and Legal Practice in the Age of American Enterprise, 1870-1920," in Gerald Geison (ed.), Professions and Professional Ideologies in America. Chapel Hill: University of North Carolina Press.

(1984b) "Critical Legal Histories," 36 Stanford Law Review 57.

GOULD, Stephen Jay (1982) "Is a New and General Theory of Evolution Emerging?" in John M. Smith (ed.), Evolution Now: A Century After Darwin. New York: W. H. Freeman Press.

GOULD, Stephen Jay, and Niles ELDREDGE (1977) "Punctuated Equilibria: The Tempo and Mode of Evolution Reconsidered," 3 Paleobiology 115.

GOULDNER, Alvin (1970) The Coming Crisis of Western Sociology. New York: Basic Books.

GRAHAM, Fred (1970) The Due-Process Revolution: The Warren Court's Impact on Criminal Law. New York: Hayden Book Co.

GRAYSTON, Richard W. (1973) "Deterrence in Automobile Liability Insurance-The Empirical Evidence," 40 Insurance Counsel Journal 117.

GREEN, Thomas (1985) Verdict According to Conscience. Chicago: University of Chicago Press.

GREEN, William (1987) "Natural Gas Policy Act in the Federal Courts: Judicial Policymaking 1978-1987." Presented at the Annual Meeting of the Law and Society Association, Washington, DC.

GREENHOUSE, Carol J. (1986) Praying for Justice: Faith, Order and Community in an American Town. Ithaca, NY: Cornell University Press.

GREENHOUSE, Steven (1985) "Limiting the Auto Giant's Liability," New York Times, 15 December, p. F(6).

GRIFFITHS, John (1986) "What Is Legal Pluralism?" 24 Journal of Legal Pluralism and Unofficial Law Annotated 1.

GROSSMAN, Joel B., Herbert M. KRITZER, Kristin BUMILLER, Stephen McDOUGAL, Richard MILLER, and Austin SARAT (1982) "Dimensions of Institutional Participation: Who Uses the Courts and How?" 44 Journal of Politics 86.

GROSSMAN, Joel B., and Austin SARAT (1975) "Litigation in the Federal Courts: A Comparative Perspective," 9 Law \& Society Review 321.

GULLIVER, Philip H. (1979) Disputes and Negotiations: A Cross-cultural Perspective. New York: Academic Press.

- (1969a) "Introduction to Case Studies of Law in Non-Western Societies," in L. Nader (ed.), Law in Culture and Society. Chicago: Aldine.

(1969b) "Dispute Settlement Without Courts: The Ndendeuli of Southern Tanzania," in L. Nader (ed.), Law in Culture and Society. Chicago: Aldine.

(1963) Social Control in an African Society. London: Routledge \& Kegan Paul.

GUTIERREZ, Carlos José (1979) El Funcionamiento del Sistema Juridico. San José, Costa Rica: Editorial Juricentro.

HABERMAS, Juergen (1975) Legitimation Crisis. Boston: Beacon.

HADDOCK, David, and Christopher CURRAN (1985) "An Economic Theory of Comparative Negligence," 14 Journal of Legal Studies 49.

HAGAN, John, and Illene Nagel BERNSTEIN (1979). "The Sentence Bargaining of Upperworld and Underworld Crime in Ten Federal District Courts," 13 Law \& Society Review 467.

HALL, Jerome (1935) Theft, Law and Society. Boston: Little, Brown.

HALL, Richard (1987) Organizations: Structures, Processes and Outcomes. Englewood Cliffs, NJ: Prentice-Hall.

(1968) "Professionalization and Bureaucratization," 33 American Sociological Review 92.

HALLER, Mark H. (1979) "Plea Bargaining: The Nineteenth Century Context," 13 Law \& Society Review 273.

- (1970) "Urban Crime and Criminal Justice: The Chicago Case," 57 Journal of American History 619.

HALLIDAY, T. C. (1986) "Six Score Years and Ten: Demographic Transitions in the American Legal Profession," 20 Law \& Society Review 53.

HAMAGUCHI, Esyun (1985) "A Contextual Model of the Japanese: Toward a 
Methodological Innovation in Japanese Studies," 11 Journal of Japanese Studies 289.

HANDLER, Joel F. (1978) Social Movements and the Legal System. New York: Academic Press.

HARDING, Sandra (1986) The Science Question in Feminism. Ithaca, NY: Cornell University Press.

HARNO, Albert J. (1928). "The Working of the Parole Board and Its Relation to the Court," 19 Journal of the American Institute of Criminal Law and Criminology 83.

HARRINGTON, Christine B. (1988) "Regulatory Reform: Creating Gaps and Making Markets," 10 Law \& Policy 19.

(1985) "Socio-legal Concepts in Mediation Ideology," 9 Legal Studies Forum 33.

HARRINGTON, Christine B., and Sally Engle MERRY (1988) "Ideological Production: The Making of Community Mediation," 22 Law \& Society Review 709.

HARRIS, Roy J., Jr. (1980) "Insurers Now Settle Faster, More Cheaply After Big Air Crashes," Wall Street Journal, 11 July, p. 1.

HARTOG, Hendrik (1976) "The Public Law of a County Court: Judicial Government in Eighteenth Century Massachusetts," 20 American Journal of Legal History 282.

HARTZ, Louis (1955) The Liberal Tradition in America. New York: Harcourt, Brace.

HARVEY, A. C. (1981) The Econometric Analysis of Time Series. Oxford: Philip Allan Publishers.

HARVEY, David (1976) "Labor, Capital, and Class Struggle Around the Build Environment of Advanced Capitalist Societies," 6 Politics and Society 625.

HAYEK, Friedrich A. (1973) Law, Legislation and Liberty: A New Statement of the Liberal Principles of Justice and Political Economy, Vol. 1. London: Routledge \& Kegan Paul.

HEINZ, John P., and Edward O. LAUMANN (1983) Chicago Lawyers: The Social Structure of the Bar. New York: Russell Sage Foundation.

HENDERSON, James A., Jr., and Theodore Eisenberg (1990) "The Quiet Revolution in Products Liability: An Empirical Study of Legal Change," 37 UCLA Law Review 479.

HENNING, Friedrich-Wilhelm (1985) Wirtschafts-und Sozialgeschichte, Vol. 1: Das vorindustrielle Deutschland, 800 bis 1800. 4th ed. Paderborn: Schoningh.

HENSLER, Deborah R., William L. F. FELSTINER, Molly SELVIN, and Patricia A. EBENER (1985) Asbestos in the Courts: The Challenge of Mass Toxic Torts. Santa Monica, CA: Institute for Civil Justice.

HEUMANN, Milton (1978) Plea Bargaining: The Experiences of Prosecutors, Judges, and Defense Attorneys. Chicago: University of Chicago Press.

- (1975) "A Note on Plea Bargaining and Case Pressure," 9 Law \& Society Review 515.

HEYDEBRAND, Wolf (1990) "Government Litigation and National Policy Making: From Roosevelt to Reagan," 24 Law \& Society Review 477.

- (1983) "Technocratic Corporatism: Toward a Theory of Occupational and Organizational Transformation," in R. Hall and R. Quinn (eds.), Organizational Theory and Public Policy. Beverly Hills, CA: Sage Publications.

(1979) "The Technocratic Administration of Justice," 2 Research in Law \& Sociology 29.

(1977) "The Context of Public Bureaucracies: An Organizational Analysis of Federal District Courts," 11 Law \& Society Review 759.

(1973) Comparative Organizations: The Results of Empirical Research. Englewood Cliffs, NJ: Prentice-Hall.

HEYDEBRAND, Wolf, and Carroll SERON (1990) Rationalizing Justice: The Political Economy of Federal District Courts. Albany, NY: SUNY Press.

- (1987) "The Organizational Structure of Courts: Toward the Technocratic Administration of Justice," 2 International Review of Sociology 63. (1986) "The Rising Demand for Court Services: A Structural Explanation of the Caseload of U.S. District Courts," 11 Justice System Journal 303. 
HIEMSCH, Jan (1964) Die bremische Gerichtsverfassung von der ersten Gerichtsordnung bis zur Reichsjustizgesetzgebung 1751-1879. Bremen: Schuenemann.

HIGGINS, Richard S., and Paul H. RUBIN (1980) "Judicial Discretion," 9 Journal of Legal Studies 129.

HINDUS, Michael S., Theodore M. HAMMETT, and Barbara M. HOBSON (1979) The Files of the Massachusetts Superior Court, 1859-1959: An Analysis and a Plan for Action. Boston: G. K. Hall.

HOFFMAN, Elizabeth, and Matthew SPITZER (1982) "The Coase Theorem: Some Experimental Tests," 25 Journal of Law and Economics 73.

HOFSTRA LAW REVIEW (1980) "Symposium on Efficiency as a Legal Concern," 8(3) Hofstra Law Review.

HOGARTH, Robin M., and Melvin W. REDER (eds.) (1987) Rational Choice: The Contrast Between Economics and Psychology. Chicago: University of Chicago Press.

HONDRICH, Karl Otto (1987) "Micropathology and Macronormality," in Jeffrey C. Alexander, Bernhard Giesen, Richard Munch, and Neil J. Smelser (eds.), The Micro-Macro Link. Berkeley: University of California Press.

HOOKER, M. B. (1975) Legal Pluralism: An Introduction to Colonial and Neo-colonial Laws. Oxford: Oxford University Press.

HORWITZ, Morton J. (1977) The Transformation of American Law, 1780-1860. Cambridge, MA: Harvard University Press.

HUNT, Alan (1978) The Sociological Movement in Law. Philadelphia: Temple University Press.

HURST, James Willard (1980-81) "The Functions of Courts in the United States: 1950-1980," 15 Law \& Society Review 401.

(1964) Law and Economic Growth: The Legal History of the Lumber Industry in Wisconsin, 1836-1916. Cambridge, MA: Belknap Press.

(1959) "Introduction," in Francis W. Laurent, The Business of a State Trial Court. Madison: University of Wisconsin Press.

(1956) Law and the Conditions of Freedom in the Nineteenth Century United States. Madison: University of Wisconsin Press.

(1950) The Growth of American Law: The Law Makers. Boston: Little, Brown.

IETSWAART, Heleen F. P. (1990) "The International Comparison of Court Caseloads: The Experience of the European Working Group," 24 Law \& Society Review 571.

(1987) "Problems of the International Comparison of Court Caseloads." Presented at the Annual Meeting of the Law and Society Association, Washington, DC.

(1986a) "L'évolution du contentieux civil aux tribunaux d'instance, 1970-1984," Rapport de Recherche, CRIV/CAFI, Paris.

- (1986b) "Evolutionary Trends in Litigation in French County Courts, 1970-1984, or, May Litigation Be Compared Cross-nationally?" Presented at the Annual Meeting of the Law and Society Association, Chicago.

- (1984) "Court Caseloads and What They Can Tell Us About Litigation and Litigiousness: The Case of France, 1971-1981." Presented at the Conference on Litigation, Gummersbach, West Germany (Theodor Heuss Academie).

ILLINOIS ASSOCIATION FOR CRIMINAL JUSTICE (1929) The Illinois Crime Survey. Chicago: Blakely Printing Co.

ILLINOIS, CRIMINAL COURT OF COOK COUNTY (1926) In Re Investigation of Charges of the Chicago Crime Commission and Frank J. Loesch. Chicago: Gunthorp-Warren.

ILLINOIS LAW REVIEW (1936) "Legislative Abolition of Certain Actions Designed to Protect the Family Relation," 20 Mlinois Law Review 764.

INDIANAPOLIS NEWS (1935) "Aching Hearts Are Itching Palms, Says Woman Legislator as Men Gallantly Pass 'Love Bill'," Indianapolis News, 1 February, p. 1.

INSTITUTO NACIONAL DE ESTADISTICA (1987) 45 Anuario Estadistico de Espana, Ano 1987. [Manual] Madrid: INE. (1950-54, 1987) 25-29, 61 Anuario Estadistico de Espana. Madrid: INE. (1986) 63 Boletin de Estadisticas (Jan.-Feb., No. 457). Madrid: INE. (1959-87) Estadisticas Judiciales de Espana. Madrid: INE. 
ISTITUT CENTRALE DI STATISTICA (1987) Annuario Statistico Italiano. Rome: ICS.

- (1973-84) 20-29 Annuario de Statistiche Giudiziarie. Rome: ICS. '(1968) Sommario de Statistiche Storiche dell' Italia, 1861-1965. Rome: ICS.

JACKSON, Cindy J. (1983) "A Controversial Settlement Approach: The Alpert Letter," 49 Journal of Air Law and Commerce 213.

JACOB, Herbert (1983a) "Courts as Organizations," in Keith O. Boyum and Lynn Mather (eds.), Empirical Theories About Courts. New York: Longman.

(1983b) "Trial Courts in the United States: The Travails of Exploration," 17 Law \& Society Review 407.

(1972) Justice in America. Boston: Little, Brown.

JACOBSSON, Bengt (1988) Kraftsamlingen: Politik och Soretigande I Parallella Processer. Lund: Doxa Ekonomi.

JANSON, Donald (1988) "Cigarette Maker Assessed Damages in Smoker's Death," Newo York Times, 14 June, p. 1.

JOHNSON, Earl, Jr. (1980-81) "Lawyers" Choice: A Theoretical Appraisal of Litigation Investment Decisions," 15 Law \& Society Review 567.

JOHNSON, Earl Jr., S. BLACK, A. DREW, William FELSTINER, E. HANSEN, and G. SABAGH (1977) Comparative Analysis of the Statistical Dimensions of the Justice Systems of Seven Industrial Democracies. A Report Submitted to the National Institute for Law Enforcement and Criminal Justice. Santa Monica, CA: Institute for Civil Justice.

JOHNSON, Kirk (1985) "Why References Aren't as Often 'Available on Request'; What Companies Say About Ex-Employees May Spawn a Lawsuit," Los Angeles Daily Journal, 14 June, p. 4.

JOHNSON, William R. (1978) Schooled Lawyers: A Study in the Clash of Professional Cultures. New York: New York University Press.

KAGAN, Richard L. (1981) Lawsuits and Litigants in Castile, 1500-1700. Chapel Hill: University of North Carolina Press.

KAGAN, Robert A. (1984) "The Routinization of Debt Collection: An Essay on Social Change and Conflict in the Courts," 18 Law \& Society Review 323.

KAGAN, Robert, Bliss CARTWRIGHT, Lawrence FRIEDMAN, and Stanton WHEELER (1978) "The Evolution of State Supreme Courts," 76 Michigan Law Review 961.

- (1977) "The Business of State Supreme Courts 1870-1970," 30 Stanford Law Review 121.

KAHNEMAN, Daniel, Jack L. KNETSCH, and Richard H. THALER (1987) "Fairness and the Assumptions of Economics," in Robin M. Hogarth and Melvin W. Reder (eds.), Rational Choice: The Contrast Between Economics and Psychology. Chicago: University of Chicago Press.

KAHNEMAN, Daniel, and Amos TVERSKY (1979) "Prospect Theory: An Analysis of Decision Under Risk," 47 Econometrica 263.

KAISER, Colin (1980) "The Deflation in the Volume of Litigation at Paris in the Eighteenth Century and the Waning of the Old Judicial Order," 10 European Studies Review 309.

KAKALIK, James S., Patricia A. EBNER, William L. F. FELSTINER, Gus W. HAGGSTROM, and Michael G. SHAPNLEY (1984) Variation in Asbestos Litigation, Compensation and Expenses. Santa Monica, CA: Institute for Civil Justice.

KASSERMAN, David Richard (1986) Fall River Outrage: Life, Murder, and Justice in Early Industrial New England. Philadelphia: University of Pennsylvania Press.

KATZ, Avery (1988) "Judicial Decisionmaking and Litigation Expenditure," 8 International Review of Law Economics 127.

KELLENBENZ, Hermann (1977) Deutsche Wirtschftsgeschichte, Vol. 1: Vor den Anfangen bis zum Ende des 18. Jahrhunderts. Munich: Beck.

KELLEY, Robert (1987) "The Westward Movement, Reconceived Within a Transatlantic Framework," 15 Reviews in American History 213.

KEYES, Charles F. (1977) The Golden Peninsula: Culture and Adaptation in Mainland Southeast Asia. New York: Macmillan. 
KIDDER, Robert (1983) Connecting Law and Society. Englewood Cliffs, NJ: Prentice Hall.

(1980-81) "The End of the Road? Problems in the Analysis of Disputes," 15 Law \& Society Review 717.

(1979) "Toward an Integrated Theory of Imposed Law," in Sandra B. Burman and Barbara E. Harrell-Bond (eds.), The Imposition of Law. New York: Academic Press.

- (1975) "Afterword: Change and Structure in Dispute Processing," 9 Law \& Society Review 385.

KORNHAUSER, Lewis (1983) "Control of Conflicts of Interest in Class Action Suits," 41 Public Choice 145.

KORNHAUSER, Lewis, and Lawrence SAGER (1986) "Unpacking the Court," 96 Yale Law Journal 82.

KRISLOV, Samuel (1986) "Afterword," 11 Justice System Journal 360. (1983) "Theoretical Perspectives on Case Load Studies: A Critique and a Beginning," in Keith O. Boyum and Lynn Mather (eds.), Empirical Theories About Courts. New York: Longman.

KURCZEWSKI, Jacek, and Kazimierz FRIESKE (1977) "Some Problems in the Legal Regulation of the Activities of Economic Institutions," 11 Law \& Society Review 489.

KURIAN, George Thomas (1987) Encyclopedia of the Third World. 3d ed. New York: Facts on File, Inc.

LANDES, Elizabeth, M. (1982) "Insurance, Liability and Accidents: A Theoretical and Empirical Investigation of the Effect of No-Fault Accidents," 25 Journal of Law and Economics 49.

LANDES, William M., and Richard A. POSNER (1979) "Adjudication as a Private Good," 8 Journal of Legal Studies 235.

LADINSKY, Jack, and Charles SUSMILCH (1983) "Major Findings of the Milwaukee Consumer Dispute Study," in Larry Ray and Deborah Smolover (eds.), Consumer Dispute Resolution: Exploring the Alternatives. Washington, DC: American Bar Association.

LANGBEIN, John H. (1979) "Understanding the Short History of Plea Bargaining," 13 Law \& Society Review 261.

LANGERWERF, Etienne (1978) "De invloed van de industrialisering op de activiteiten van hoven en rechtbanken," 32 Economisch en Social Tijdschrift 215.

(n.d) "The Conciliation Procedure of Dismissal Cases Before the Belgium Labour Courts: A Historical Analysis." Unpublished paper, Center for Sociology of Law, University of Antwerp.

LANGERWERF, Etienne, and J. VAN HOUTTE (1979) "Een verklaringsmodel voor de verschillen in procesvoeringsratio van de burgerlijke Rechtbanken van eerste aanleg," 24 Tijdschrift voor Sociale Wetenschappen 74 .

LANGERWERF, Etienne, and Francis VAN LOON (1985) "Evolution of Litigation Patterns in Belgium, 1970-1984." Presented at the World Congress of Sociology of Law, Aix-en-Provence, France.

(1984) "Evolution of the Activities of the Courts in Belgium from 1970-1980." Presented at the Conference on Litigation at Gummersbach, West Germany (Theodor Heuss Academie).

LASCH, Christopher (1977) Haven in a Heartless World: The Family Besieged. New York: Basic Books.

LAURENT, Francis W. (1959) The Business of a Trial Court: 100 Years of Cases. Madison: University of Wisconsin Press.

LAW \& SOCIETY REVIEW (1988) "Law and Ideology," 22(4) Law \& Society Review (Special Issue).

(1985) Issue on Courts and Legal Change in Historical Perspective. 19(3) Law \& Society Review (Thematic issue).

(1980-81) "Dispute Processing and Civil Litigation," 15(3\&4) Law \& Society Review (Special Issue).

(1975) "Litigation and Dispute Processing, Part Two," 9(2) Law \& Society Review (Special Issue).

(1974) "Litigation and Dispute Processing, Part One," 9(1) Law \& Society Review (Special Issue). 
LEHMAN, Edward W. (1988) "The Theory of the State Versus the State of Theory," 53 American Sociological Review 807.

LEMPERT, Richard D. (1990) “Docket Data and 'Local Knowledge': Studying the Court and Society Link Over Time," 24 Law and Society Review 301.

(1989) "The Dynamics of Informal Procedure: The Case of a Public Housing Eviction Board," 23 Law \& Society Review, 347.

(1980-81) "Grievances and Legitimacy: The Beginnings and End of Dispute Settlement," 15 Law \& Society Review 707.

(1978) "More Tales of Two Courts: Exploring Changes in the 'Dispute Settlement Function' of Trial Courts," 13 Law \& Society Review 91.

(1966) "Strategies of Research Design in the Legal Impact Study: The Control of Plausible Rival Hypotheses," 1 Law \& Society Review 111.

LEMPERT, Richard, and Karl MONSMA (1988) "Lawyers and Informal Justice: The Case of a Public Housing Eviction Board," 51 Law and Contemporary Problems 135.

LEMPERT, Richard, and Joseph SANDERS (1986) An Invitation to Law and Social Science. New York: Longman.

LEUNG, Kwok, and E. Allan LIND (1986) "Procedural Justice and Culture: Effects of Culture, Gender and Investigator Status on Procedural Preferences," 50 Journal of Personality and Social Psychology 1134.

LEVIN, Martin A. (1971) "Urban Politics and Judicial Behavior," 1 Journal of Legal Studies 193.

LEWIN, Tamar (1985) "Pharmaceutical Companies Are Hardest Hit," New York Times, 10 March, p. 1, sec. 3.

LEWIS-BECK, Michael S. (1986) "Interrupted Time Series," in William D. Berry and Michael S. Lewis-Beck (eds.), New Tools for Social Scientists. Beverly Hills, CA: Sage Publications.

LIEBERMAN, Jethro K. (ed.) (1984) The Role of Courts in American Society: The Final Report of the Council on the Role of Courts. St. Paul, MN: West Publishing Co.

LINDSEY, Robert (1985) "Businesses Change Ways in Fear of Lawsuits," Chicago Daily Law Bulletin, 20 November, p. 2.

LLEWELLYN, Karl, and E. Adamson HOEBEL (1941) The Cheyenne Way: Conflict and Case Law in Primitive Jurisprudence. Norman: University of Oklahoma Press.

LLOYD-BOSTOCK, Sally (1983a) "Fault and Liability for Accidents: The Accident Victim's Perspective," in C. Harris (ed.), Compensation for Mlness and Injury. Oxford: Centre for Socio-Legal Studies.

- (1983b) "Attributions of Cause and Responsibility as Social Phenomena," in Jos Jaspars, Frank D. Fincham, and Miles Hewstone (eds.), Attribution Theory and Research: Conceptual, Developmental and Social Dimensions. New York: Academic Press.

LORCH, Robert S. (1969) Democratic Process and Administrative Law. Detroit: Wayne State University Press.

LOWENTHAL, Max (1950) The Federal Bureau of Investigation. New York: William Sloane Associates.

LUHMANN, Niklas (1983) "The Self-Reproduction of the Law and Its Limits." Presented at the Conference on Reflexive Law and the Regulatory Crisis, Madison, WI.

- (1982) The Differentiation of Society. Trans. by S. Holmes and C. Larmore. New York: Columbia University Press.

(1981) "Communication About Law in Interaction Systems," in K. Knorr-Cetina and A. V. Cicourel (eds.), Advances in Social Theory and Methodology: Toward an Integration of Micro- and Macro-Sociologies. Boston: Routledge \& Kegan Paul.

LUKES, Steven, and Andrew SCULL (eds.) (1983) Durkheim and the Law. New York: St. Martin's Press.

MACAULAY, Stewart (1985) "An Empirical View on Contract," 1985 Wisconsin Law Review 3.

L (1983) "Private Government," Working Paper 1983-6, Disputes Processing Research Program, Madison, WI. Also published in L. Lipson and S. Wheeler (eds.), Law and Social Sciences. New York: Russell Sage Foundation, 1986. 
(1977) "Elegant Models, Empirical Pictures and the Complexities of Contract," 11 Law \& Society Review 507.

(1966) Law and the Balance of Power: The Automobile Manufacturers and Their Dealers. New York: Russell Sage Foundation.

(1963) "Non-contractual Relations in Business: A Preliminary Study," 28 American Sociological Review 55.

MacCALL, Morgan, W., and Robert E. KAPLAN (1985) Whatever It Takes: Decision Makers at Work. Englewood Cliffs, NJ: Prentice Hall.

MACEY, Jonathan (1986) "Promoting Public-regarding Legislation Through Statutory Interpretation: An Interest Group Model," 86 Columbia Law Review 223.

MacNEIL, Ian R. (1985) "Relational Contract: What We Do and Do Not Know," 1985 Wisconsin Law Review 3.

- (1980) The New Social Contract. An Inquiry into Modern Contractual Relations. New Haven, CT.: Yale University Press.

MacPHERSON, C. B. (1962) The Political Theory of Possessive Individualism: Hobbes to Locke. Oxford: Clarendon Press.

MANNHEIM, Karl (1936) Ideology and Utopia: An Introduction to the Sociology of Knowledge. New York: Harcourt, Brace.

MANNING, Bayless (1977) "Hyperlexis: Our National Disease," 71 Northwestern University Law Review 767.

MARITIME AND COMMERCIAL COURT OF DENMARK (1986) "Statistical Information," in So-og Handelsretten gennem 125. Copenhagen: Maritime and Commercial Court.

MARVELL, Thomas B. (1987) "Caseload Growth-Past and Future Trends," 71 Judicature 151.

(1985) "Civil Caseloads: The Impact of the Economy on Trial Judgeship Increase," 69 Judicature 153.

MATHER, Lynn (1990) "Dispute Processing and A Longitudinal Approach to Courts," 24 Law \& Society Review 357.

- (1979a) Plea Bargaining or Trial? The Process of Criminal-Case Disposition. Lexington, MA: Lexington Books.

(1979b) "Comments on the History of Plea Bargaining," 13 Law \& Society Review 281.

MATHER, Lynn, and Barbara Yngvesson (1980-81) "Language, Audience, and the Transformation of Disputes," 15 Law \& Society Review 775.

MAURICE, Marc, Francois SELLIER, and Jean Jacques SILVESTRE (1979) "La Production de la hierarchie dans l'entreprise: recherche d'un effet societal; comparison France-Allemagne," 20 Revue Francaise de Sociologie 331.

MAYHEW, Leon H., and Albert J. REISS, Jr. (1969) "The Social Organization of Legal Contacts," 34 American Sociological Review 309.

McDONALD, Terrence J. (1987) "Building the Impossible State: A Polity Centered Approach to State Building in America, 1820-1930." in John E. Jackson (ed.), Essays in American Institutions. Ann Arbor: University of Michigan Press.

(1986) The Parameters of Urban Fiscal Policy: Socioeconomic Change, Political Culture, Policy in San Francisco, 1860-1906. Berkeley: University of California Press.

McDONALD, Terrence, and Sally WARD (1984) The Politics of Urban Fiscal Policy. Beverly Hills, CA: Sage Publications.

McEWEN, Craig A., and Richard J. MAIMAN (1986) "The Relative Significance of Disputing Forum and Dispute Characteristics for Outcome and Compliance," 20 Law \& Society Review 439.

(1984) "Mediation in Small Claims Court: Achieving Compliance Through Consent," 18 Law \& Society Review 11.

McGOVERN, Francis E. (1986) "Toward a Functional Approach for Managing Complex Litigation," 53 University of Chicago Law Review 440.

McGUIRE, E. Patrick (1988) "The Impact of Product Liability." Research Report No. 908 of the Conference Board, New York, NY.

McHUGH, Carol (1983) "Specialties Create Need for Exotic Publications," Chicago Daily Law Bulletin, 21 March, p. 1.

McINTOSH, Wayne V. (1990) The Appeal of Civil Law: A Political-economic Analysis of Litigation. Urbana: University of Illinois Press. 
(1985) “A State Court's Clientele: Exploring the Strategy of Trial Litigation," 19 Law \& Society Review 421.

(1983) "Private Use of a Public Forum: A Long-Range View of the Dispute Processing Role of Courts," 77 American Political Science Review 991.

- (1980-81) "150 Years of Litigation and Dispute Settlement: A Court Tale," 15 Law \& Society Review 823.

MENKEL-MEADOW, Carrie (1985) "The Transformation of Disputes by Lawyers: What the Dispute Paradigm Does and Does Not Tell Us," 1985 Missouri Journal of Dispute Resolution 25.

- (1983) "Legal Negotiation: A Study of Strategies in Search of a Theory," 1983 American Bar Foundation Research Journal 905.

MERRY, Sally Engle (1985) "Concepts of Law and Justice Among WorkingClass Americans: Ideology as Culture," 9 Legal Studies Forum 59.

(1982) "Toward the General Theory of Gossip and Scandal," in D. Black (ed.), Toward a General Theory of Social Control. Orlando, FL: Academic Press.

(1979) "Going to Court: Strategies of Dispute Management in an American Urban Neighborhood," 13 Law \& Society Review 891.

MERRY, Sally Engle, and Susan S. SILBEY (1984) "What Do Plaintiffs Want? Reexamining the Concept of Dispute," 9 Justice System Journal 151.

MERRYMAN, John Henry, and David S. CLARK (1978) Comparative Law: Western European and Latin American Legal Systems. Indianapolis: Bobbs-Merrill.

MERRYMAN, John Henry, David S. CLARK, and Lawrence M. FRIEDMAN (1979) Law and Social Change in Mediterranean Europe and Latin America. Dobbs Ferry, NY: Oceana Publications.

MERTON, Robert K. (1965) "Durkheim's Division of Labor in Society," in Robert Nisbet (ed.), Emile Durkheim. Englewood Cliffs, NJ: Prentice Hall.

MERZ, Charles (1931) The Dry Decade. Garden City, NY: Doubleday, Doran \& Co.

MESSINGER, Sheldon L., John E. BEROCHEA, David RAUMA, and Richard A. BERK (1985) "The Foundations of Parole in California," 19 Law \& Society Review 69.

MEZEY, Susan Gluck (1987) "Conflict over the Rule of Law: Nonacquiescence by the Social Security Administration." Presented at Annual Meeting of the Law and Society Association, Washington, DC.

MIGUEL Y ROMERO, Mauro, and Carlos de MIGUEL Y ALONSO (1967) Derecho Procesal Practico, Vol. 1. 11th ed. Barcelona: Bosch, Casa Editorial.

MILLER, Geoffrey P. (1986) "An Economic Analysis of the Rule 68," 15 Journal of Legal Studies 93.

MILLER, Herbert S., William F. McDONALD, and James A. CRAMER (1978) Plea Bargaining in the United States. Washington, DC: National Institute of Law Enforcement and Criminal Justice.

MILLER, Richard E., and Austin SARAT (1980-81) "Grievances, Claims and Disputes: Assessing and Adversary Culture," 15 Law \& Society Review 525.

MILLER, Wilbur R. (1986) "Police and the State: A Comparative Perspective," 1986 American Bar Foundation Research Journal 339.

MILLSPAUGH, Arthur C. (1937) Crime Control by the National Government. Washington, DC: Brookings Institution. (1936) Local Democracy and Crime Control. Washington, DC: Brookings Institution.

MINCHINTON, Walter (1976) "Patterns of Demand 1750-1914," in Carlo M. Cipolla (ed.), The Fontana Economic History of Europe. Vol. 3. New York: Harvester Press.

MINISTERE DE LA JUSTICE (1970-1984) Annuaire Statistique de la Justice. Paris: La Documentation Francaise.

MITCHELL, Cynthia F., and Paul M. BARRETT (1988) "Novel Effort to Settle Asbestos Claims Fails as Lawsuits Multiply," Wall Street Journal, 7 June, p. 1.

MIYAZAWA, Setsuo (1987) "Taking Kawashima Seriously: A Review of Japa- 
nese Research on Japanese Legal Consciousness and Disputing Behavior," 21 Law \& Society Review 219.

MNOOKIN, Robert H., and Lewis KORNHAUSER (1979) "Bargaining in the Shadow of the Law: The Case of Divorce," 88 Yale Law Journal 950.

MOLEY, Raymond (1928) "The Vanishing Jury," 2 Southern California Law Review 97.

MONKKONEN, Eric H. (1990) "The American State from the Bottom Up: Of Homicides and Courts," 24 Law \& Society Review 521.

- (1988) America Becomes Urban: The Development of U.S. Cities and Towns, 1780-1980. Berkeley: University of California Press.

- (1984a) "The Politics of Municipal Indebtedness and Default, 1850-1936," in Terrence McDonald and Sally Ward (eds.), The Politics of Urban Fiscal Policy. Beverly Hills, CA: Sage Publications.

- (1984b) "Why Is the History of Crime in the United States Different from the History of Crime in Britain?" Presented at the International Conference on Violence in History, Maastrict, Netherlands.

(1975) The Dangerous Class: Crime and Poverty in Columbus, Ohio, 1860-1885. Cambridge, MA: Harvard University Press.

MOORE, Sally Falk (1990) "Remarks: Roundtable on Silences in Research and Theory: The Role of the State in Sociolegal Studies," 10 Law, Politics and Society (forthcoming).

- (1987) "Social Facts and Fabrications: 'Customary' Law on Kilimanjaro, 1880-1980," 19 New York University Journal of International Law \& Politics 524.

- (1978) Law as Process: An Anthropological Approach. London: Routledge \& Kegan Paul.

- (1972) "Legal Liability and Evolutionary Interpretation," in M. Gluckman (ed.), The Allocation of Responsibility. Manchester: Manchester University Press.

MOORE, Sally Falk et al. (1990) "Roundtable on Silences in Research and Theory: The Role of the State in Sociolegal Studies," 10 Law, Politics and Society (forthcoming).

MORNET, Francois (1980) La Justice et le recouvrement de l'impaye: qui est saisi, comment et pourquoi. Paris: La Documentation Francaise.

MUNGER, Frank (1988) "Law, Change and Litigation: A Critical Examination of an Empirical Research Tradition," 22 Law \& Society Review 57. - (1987a) "Social Change and Tort Litigation: Industrialization, Accidents, and Trial Courts in Southern West Virginia, 1872 to $1940, " 36$ Buffalo law Review 75.

L (1987b) "Businesses and Litigation in the Progressive Era." Presented at the Conference on Longitudinal Research on Trial Courts, Buffalo, New York.

- (1986a) "Commercial Litigation in West Virginia State and Federal Courts 1870-1940," 30 American Journal of Legal History 322.

(1986b) "Longitudinal Research on Trial Courts: The Gap Between Present Results and Future Potential." Proposal submitted to the National Science Foundation.

NADER, Laura (ed.) (1980) No Access to Law: Alternatives to the American Judicial System. New York: Academic Press.

- (1969a) Law in Culture and Society. Chicago: Aldine.

- (1969b) "Styles of Court Procedure: To Make the Balance," in L. Nader (ed.), Law in Culture and Society. Chicago: Aldine.

- (1965) "Choices in Legal Procedure: Shia Moslem and Mexican Zapotec," 67 American Anthropologist 394.

NADER, Laura, and Harry F. TODD, Jr. (eds.) (1978) The Disputing Process: Law in Ten Societies. New York: Columbia University Press.

NATIONAL CENTER FOR STATE COURTS (1984) “A Preliminary Examination of Available Civil and Criminal Trend Data in State Trial Courts for 1978, 1981, and 1984," in Robert Roper (ed.), State Court Caseload Statistics: Annual Report, 1984. Williamsburg, VA: National Center for State Courts.

NELSON, Robert (1988a) Partners with Power: Social Transformation of the Large Law Firm. Berkeley: University of California Press. 
(1988b) "Ideology, Scholarship, and Sociological Change: Lessons from Galanter and the 'Litigation Crisis'," 21 Law \& Society Review 677.

(1981) "Practice and Privilege: Social Change and the Structure of Large Law Firms," 1981 American Bar Foundation Research Journal 95.

NEWMAN, Katherine, and Paul ATTEWELL (1985) "A Compliance-Resource Theory of Regulatory Failure: The Case of OSHA," 5 International Journal of Sociology and Social Policy 29.

NEW YORK SECRETARY OF STATE (1905) Annual Report on Statistics of Crime. Albany, NY.

NEW YORK SECRETARY OF STATE (1857) Report of the Secretary of State on the Criminal Statistics of the State of New York. Albany, NY.

NOBEL, David F. (1977) America by Design. New York: Knopf.

O'CONNOR, James (1973) The Fiscal Crisis of the State. New York: St. Martins.

OFFE, Claus (1984) Contradictions of the Welfare State. Cambridge, MA: MIT Press.

- (1981) "The Attribution of Public Status to Interest Groups: Observations on the West German Case," in S. Berger (ed.), Organizing Interests in Western Europe: Pluralism, Corporatism, and the Transformation of Politics. Cambridge: Cambridge University Press.

ORLANDO, Jacqueline (1988) "Asbestos Litigation and the Ohio Asbestos Litigation Plan: Insulating the Courts from the Heat," 3 Ohio Journal of Dispute Resolution 399.

PADGETT, John F. (1990) "Plea Bargaining and Prohibition in the Federal Courts, 1908-1934," 24 Law \& Society Review 413.

- (1985) "The Emergent Organization of Plea Bargaining," 90 American Journal of Sociology 753.

PALMER, Ian (1985) "State Theory and Statutory Authorities: Points of Convergence," 19 Sociology 523.

PELLER, Gary (1985) "The Metaphysics of American Law," 78 California Law Review 1152.

PERLOFF, Jeffery M., and Daniel L. RUBINFELD (1988) "Settlements in Private Antitrust Litigation," in Steven Salop and Lawrence White (eds.), Antitrust Litigation. Cambridge, MA: MIT Press.

PETERSON, M. A., and G. PRIEST (1982) The Civil Jury: Trends in Trials and Verdicts, Cook County, Mlinois, 1960-1979. Santa Monica, CA: Institute for Civil Justice.

PIERSON, Christopher (1984) "New Theories of State and Civil Society: Recent Developments in Post-Marxist Analysis of the State," 18 Sociology 563.

PINDYCK, Robert S., and Daniel L. RUBINFELD (1989) Microeconomics. New York: Macmillan.

PINSEAU, Hubert (1985) L'organisation judiciaire de la France. Paris: La Documentation Francaise.

PLOTT, Charles R. (1987) "Rational Choice in Experimental Markets," in Robin M. Hogarth and Melvin W. Reder (eds.), Rational Choice: The Contrast Between Economics and Psychology. Chicago: University of Chicago Press.

P'NG, Ivan Paak Liang (1983) "Strategic Behavior in Suit, Settlement, and Trial," 14 Bell Journal of Economics 539.

POLINSKY, A. Mitchell, and Daniel L. RUBINFELD (1988) "The Welfare Implications of Costly Litigation for the Theory of Liability," 17 Journal of Legal Studies 151.

POLLACK, Friederick, and Frederick William MAITLAND [1985] (1968) The History of English Law from Edward II. 2 Vols. Cambridge: Cambridge University Press.

POSNER, Richard A. (1986) Economic Analysis of Law. 3d Ed. Boston: Little, Brown.

- (1985) The Federal Courts: Crisis and Reform. Cambridge, MA: Harvard University Press.

POTTER, Sulamith Heins (1977) Family Life in a Northern Thai Village: A Study in the Structural Significance of Women. Berkeley: University of California. 
POUND, Roscoe (1930) Criminal Justice in America. Cambridge, MA: Harvard University Press.

PRIEST, George (1987) "Measuring Legal Change," 3 Journal of Law and Economic Organization 193.

(1977) "The Common Law Process and the Selection of Efficient Rules," 6 Journal of Legal Studies 65.

PRIEST, G. L., and B. KLEIN (1984) The Selection of Disputes for Litigation. Santa Monica, CA: Rand Corp.

PROULX, Marcel (1986) La gestion de cing Tribunaux d'instance de la region parisienne. Paris: IEP.

PROVINE, D. Marie (1985) Settlement Strategies of Federal District Judges. Washington, DC: Federal Judicial Center.

PRZEWORSKI, Adam (1985) Capitalism and Social Democracy. Cambridge: Cambridge University Press.

PURNICK, Joyce (1985) "A Downtown Dig for Artifacts from the Days of Old Breukelen," New York Times, 1 September, p. 42.

RABIBHADANA, M. R. Akin (1969) The Organization of Thai Society in the Early Bangkok Period, 1782-1873. Ithaca, NY: Southeast Asia Program, Cornell University.

RAMOS MÉNDEZ, Francisco (1986) Derecho Procesal Civil, Vols. 1 and 2. 3d ed. Barcelona: Libreria Bosch.

RANIERI, Filippo (1985) Recht und Gesellschaft im Zeitalter der Rezeption, 2 vols. Cologne: Bohlau.

RANII, David (1985) "New Group Takes Aim at the Tobacco Industry," National Law Journal, 11 February, p. 4.

RASLER, Karen (1986) "War, Accommodation, and Violence in the United States, 1890-1970," 80 American Political Science Review 921.

REED, Alfred Z. (1928) Present-Day Law Schools in the United States and Canada. New York: Carnegie Foundation for the Advancement of Teaching.

(1921) Training for the Public Profession of the Law. New York: Carnegie Foundation.

REISS, A. J., Jr. (1990) "Longitudinal Study of Trial Courts," 24 Law \& Society Review 345.

- (1974) "Citizen Access to Criminal Justice," 1 British Journal of Law and Society 50.

REISS, A. J., Jr., and A. D. BIDERMAN (1980) Data Sources on White-Collar Law-breaking. Washington, DC: National Institute of Justice.

REISS, A. J., JR., and D. BORDUA (1967) "Environment and Organization: A Perspective on the Police," in D. Bordua (ed.), The Police: Six Sociological Essays. New York: John Wiley.

RESNIK, Judith (1982) "Managerial Judges," 96 Harvard Law Review 376.

RHEINGOLD, Paul D. (1982) "The Development of Litigation Groups," 6 American Journal of Trial Advocacy 1.

- (1968) "The MER/29 Story-An Instance of Successful Mass Litigation," 56 California Law Review 116.

RICHARDS, William, and Barry MEIER (1987) "Lawyers Lead Hunt for New Groups of Asbestos Victims," Wall Street Journal, Feb. 18, p. 1.

RIKER, William H., and Barry WEINGAST (1988) "Constitutional Regulation of Legislation: The Consequences of Judicial Deference," 74 Virginia Law Review 373.

ROSE, Richard (1978) "Ungovernability: Is There Fire Behind the Smoke?" 27 Political Studies 351.

ROSE-ACKERMAN, Susan (1988) "Progressive Law and Economics-and the New Administrative Law," 98 Yale Law Journal 341.

ROSENFELD, Andrew (1976) "An Empirical Test of Class-Action Settlement," 5 Journal of Legal Studies 113.

ROSENTHAL, Douglas (1974) Lawyer and Client: Who's in Charge? New York: Russell Sage Foundation.

ROSS, H. Laurence (1970) Settled Out of Court: The Social Process of Insurance Claims Adjustment. Chicago: Aldine.

ROTTLEUTHNER, H. (1985) "Aspekte der Rechtsentwicklung in Deutschland. Ein soziologischer Vergleich Deutscher Rechtskulturen," 6 Zeitschrift für Rechtssoziologie 206. 
RUBIN, Paul (1977) "Why Is the Common Law Efficient?" 6 Journal of Legal Studies 51.

RUBINFELD, Daniel (1987) "The Efficiency of Comparative Negligence," 16 Journal of Legal Studies 375.

RUBINFELD, Daniel L., and David SAPPINGTON (1987) "Efficient Awards and Standards of Proof in Judicial Proceedings," 18 Rand Journal of Economics 308.

RUFFINI, Julio L. (1978) "Disputing over Livestock in Sardinia," in Laura Nader and H. Todd, Jr. (eds.), The Disputing Process-Law in Ten Societies. New York: Columbia University Press.

RULE, James (1978) "Models of Relevance: The Social Effects of Sociology," 84 American Journal of Sociology 78.

SANDERS, Janet (1979) "Title VII: The Boom Is Over," National Law Journal, 28 May, p. 1.

SANDERS, Joseph (1990) "The Interplay of Micro and Macro Processes in The Longitudinal Study of Courts: Beyond the Durkheimian Tradition," 24 Law \& Society Review 241.

SANDERS, Joseph, and V. Lee HAMILTON (1987) "Attribution of Responsibility and Punishment in Japan and the United States: How Big Is the Gap?" Presented at the Annual Meeting of the American Sociological Association, Chicago.

SANTOS, Boaventura de Sousa (1977) "The Law of the Oppressed: The Construction and Reproduction of Legality in Pasargada," 12 Law \& Society Review 5.

SARAT, Austin (1985) "Legal Effectiveness and Social Studies of Law: On the Unfortunate Persistence of a Research Tradition," 9 Legal Studies Forum 23.

23. (1976) "Alternatives in Dispute Processing: Litigation in Small Claims Court," 10 Law \& Society Review 339.

SARAT, Austin, and William, L. F. FELSTINER (1986) "Law and Strategy in the Divorce Lawyer's Office," 20 Law \& Society Review 93.

SARAT, Austin, and Joel B. GROSSMAN (1975) "Courts and Conflict Resolution: Problems in the Mobilization of Adjudication," 69 American Political Science Review 1200.

SARAT, Austin, and Susan SILBEY (1988) "The Pull of the Policy Audience," 10 Law \& Policy 97.

SAVONA, Ernesto Ugo (1976) "Civil Trial and Social Justice in Italy: A Sociological Analysis of Proceedings under Art. 28 of the Workers' Statute," 4 Jahrbuch für Rechtssoziologie und Rechtstheorie 207.

SCHEIBER, Harry (1975) "Federalism and the American Economic Order, 1789-1910," 10 Law \& Society Review 57.

SCHEINGOLD, Stewart (1974) The Politics of Rights. New Haven, CT: Yale University Press.

SCHELLE, Tage (1986) "The Origin of the Maritime and Commercial Court and the First Centennial," in So-og Handelsretten gennem 125 ar. Copenhagen: Maritime and Commercial Court.

SCHMECKEBIER, Laurence F. (1929) The Bureau of Prohibition: Its History, Activities and Organization. Washington, DC: Brookings Institution.

SCHNEIDER, Mark (1982) "Criminal Enforcement of Federal Water Pollution Laws in an Era of De-regulation," 73 Journal of Criminal Law and Criminology 642.

SCHUCK, Peter H. (1986) Agent Orange on Trial: Mass Toxic Diasters in the Courts. Cambridge, MA: Harvard University Press, Belknap Press.

SCHWAB, Stewart J., and Theodore EISENBERG (1988) "Explaining Constitutional Tort Litigation: The Influence of the Attorney Fees Statute and the Government as Defendant," 73 Cornell Law Review 719.

SCHWARTZ, Bernard (1984) Administrative Law. 2d ed. Boston: Little, Brown.

SCHWARTZ, Richard (1954) "Social Factors in the Development of Legal Control: A Case Study of Two Israeli Settlements," 63 Yale Law Review 471.

SCHWARTZ, Richard D., and James C. MILLER (1964) "Legal Evolution and Societal Complexity," 70 American Journal of Sociology 159. 
SCHWARZ, Klaus (1983) "Zur Einwohnerzahl Bremens im 17.Jh." Manuscript. Staatsarchiv, Bremen.

SCHWARZWÄLDER, Herbert (1975) Geschichte der Freien Hansestadt Bremen. 2 vols. Bremen: Roever.

SEIDMAN, Harold, and Robert GILMOUR (1986) Politics, Position, and Power: From the Positive to the Regulatory State. 4th ed. New York: Oxford University Press.

SELVIN, Hannan C. (1965) "Durkheim's Suicide: Further Thoughts on a Methodological Classic," in Robert A. Nisbet, Emile Durkheim. Englewood Cliffs, NJ: Prentice-Hall.

SELVIN, M., and P. EBENER (1984) Managing the Unmanageable: A History of Civil Delay in the Los Angeles Superior Court. Santa Monica, CA: Institute for Civil Justice.

SENNINGER, Erhard (1989) "Die Entwicklung der Anwaltschaft an der Schwelle des europäischen Binnenmarktes," 39 Anwaltsblatt 298.

SERON, Carroll (1990) "The Impact of Court Organization on Litigation," 24 Law \& Society Review 451.

SEWELL, William H. (1987) "Theory of Action, Dialectic, and History: Comment on Coleman," 93 American Journal of Sociology 166.

SHANLEY, M. G., and M. A. PETERSON (1983) Comparative Justice: Civil and Jury Verdicts in San Francisco and Cook Counties, 1959-1980. Santa Monica, CA: Institute for Civil Justice.

SHAPIRO, Martin M. (1981) Courts: A Comparative and Political Analysis. Chicago: University of Chicago Press.

SHARP, Lauriston, and Lucien M. HANKS (1978) Bang Chan: Social History of a Rural Community in Thailand. Ithaca, NY: Cornell University.

SHAVELL, Steven (1982) "Suit, Settlement, and Trial: A Theoretical Analysis Under Alternative Methods for the Allocation of Legal Costs," 11 Journal of Legal Studies 55.

SILBERMAN, Matthew (1985) The Civil Justice Process. Orlando, FL: Academic Press.

SILBEY, Susan (1985) "Ideals and Practices in the Study of Law," 9 Legal Studies Forum 7.

SILBEY, Susan, and Sally Engle MERRY (1986) "Mediator Settlement Strategies," 8 Law \& Policy 7.

SINCLAIR, Andrew (1962) Prohibition: The Era of Excess. Boston: Little, Brown.

SJOSTRAND, Sven-Erik (1985) Samhallsorganisation. Lund: Doxa Ekonomi.

SKOCPOL, Theda (1987) "Social History and Historical Sociology: Contrasts and Complementarities," 11 Social Science History 17.

- (1985) "Bringing the State Back in: Strategies of Analysis in Current Research," in Peter B. Evans, D. Reuschemeyer, and T. Skocpol (eds.), Bringing the State Back in. Cambridge: Cambridge University Press. (1980) "Political Response to Capital Crisis: Neo-Marxist Theories of the State and the Case of the New Deal," 10 Politics and Society 155.

SKOCPOL, Theda, and Kenneth FINEGOLD (1982) "State Capacity and Economic Intervention in the Early New Deal," 97 Political Science Quarterly 255.

SKOCPOL, Theda, and John IKENBERRY (1983) "The Political Formation of the American Welfare State in Historical and Comparative Perspective," 6 Comparative Social Research 87.

SKOWRONEK, Stephen (1982) Building a New American State: The Expansion of National Administrative Capacities, 1877-1920. Cambridge: Cambridge University Press.

SMITH, Richard A. (1961) "The Incredible Electrical Conspiracy," Fortune, April, p. 132, May, p. 161.

SMITH, Robert J. (1983) Japanese Society: Tradition, Self and the Social Order. Cambridge: Cambridge University Press.

SNYDER, Francis (1980) "Law and Development in the Light of Dependency Theory," 4 Law \& Society Review 703.

SOETENHORST-DE SAVORNIN LOHMAN, Jacqueline (1983) Zuinig met recht. Rijswijk: Sociaal en Cultureel Planbureau.

SPITZER, Matthew (1980) "Radio Formats Administrative Choice," 47 Uni. versity of Chicago Law Review 647. 
(1979) "Multicriteria Choice Processes: An Application of Public Choice Theory of Bakke, the FCC and the Courts," 88 Yale Law Journal 717.

STEINBERG, Allen (1984) "From Private Prosecution to Plea Bargaining: Criminal Prosecution, the District Attorney, and American Legal History," 30 Crime and Delinquency 568.

STERN, Gerald M. (1976) The Buffalo Creek Disaster. New York: Random House.

STINCHCOMBE, Arthur (1986) "Rationality and Social Structure," in Arthur Stinchombe (ed.), Stratification and Organization: Selected Papers. Cambridge: Cambridge University Press.

(1968) Constructing Social Theories. New York: Harcourt, Brace \& World.

(1965) "Organizations and Social Structure," in James G. March (ed.), Handbook of Organizations. Chicago: Rand McNally.

- (1959) "Bureaucratic and Craft Administration of Production: A Comparative Study," 4 Administrative Science Quarterly 168.

STOOKEY, John A. (1990) "Trial and Tribulations: Crisis, Litigation and Legal Change," 24 Law \& Society Review 497.

- (1986) "Economic Cycles and Civil Litigation," 11 Justice System Journal 282.

STRASSER, Fred (1987) “Bendectin Award: \$95 Million," National Law Journal, 27 July, p. 29.

STRAUSS, Anselm (1978) Negotiations: Varieties, Contexts, Processes, and Social Order. San Francisco: Jossey-Bass.

SUDNOW, David (1965) "Normal Crimes: Sociological Features of the Penal Code in a Public Defender Office," 12 Social Problems 255.

SUGARMAN, David (ed.) (1983) Legality, Ideology and the State. London: Academic Press.

SYLLA, Richard (1986) "Long-Term Trends in State and Local Finance: Sources and Uses of Funds in North Carolina, 1800-1977," in Stanley Engerman and Robert Gallman (eds.), Long-Term Factors in American Economic Growth. Chicago: University of Chicago Press.

TAMBIAH, S. J. (1976) World Conquerer and World Renouncer: A Study of Buddhism and Polity in Thailand Against a Historical Background. New York: Cambridge University Press.

(1970) Buddhism and the Spirit Cults in North-East Thailand. Cambridge: Cambridge University Press.

TANASE, Takao (1990) "The Management of Disputes: Automobile Accident Compensation in Japan," 24 Law and Society Review (forthcoming).

TANCREDI, L. R., and J. A. BARONDESS (1978) "The Problem of Defensive Medicine," 200 Science 879.

TARR, Amy (1985) "Lawyers Collide Over Post-Air-Crash Conduct Settlement: Litigation Tactics at Issue," National Law Journal, 4 November, p. 1.

TAYLOR, W. B. (1985) "Between Global Process and Local Knowledge: An Inquiry into Early Latin American Social History, 1500-1900," in Oliver Zunz (ed.), Reliving the Past: The Worlds of Social History. Chapel Hill: University of North Carolina Press.

TEAFORD, Jon (1984) The Unheralded Triumph: City Government in America, 1870-1900. Baltimore: John Hopkins University Press.

(1979) City and Suburb: The Political Fragmentation of Metropolitan America, 1850-1970. Baltimore: Johns Hopkins University Press.

TERWIEL, B. J. (1976) "Leasing from the Gods (Thailand)," 71 Anthropos 254.

TEUBNER, Gunther (1985) "Social Order from Legislative Noise? Autopoietic Closure as a Problem for Legal Regulation," in Autopoiesis in Law and Society. Florence: European University Institute.

- (1984) "Autopoesis in Law and Society: A Rejoinder to Blankenburg," 18 Law \& Society Review 291.

THOMAS, Stanley (1958) "Jurisdiction of Illinois County and Probate Courts," 46 Rlinois Bar Journal 606.

THOMPSON, Edward P. (1975) Whigs and Hunters: The Origin of the Black Act. New York: Pantheon.

THOMPSON, James D., and Arthur TUDEN (eds.) (1959) "Strategies, Struc- 
tures, and Processes of Organizational Decision," in J. D. Thompson and others (eds.), Comparative Studies in Administration. Pittsburgh: University of Pittsburgh Press.

TIFFANY, Lawrence P., Yakov AVICHAI, and Geoffrey W. PETERS. (1975) "A Statistical Analysis of Sentencing in Federal Courts: Defendants Convicted After Trial, 1967-1968." 4 Journal of Legal Studies 369.

TILLY, Charles (1984) Big Structures, Large Processes, and Huge Comparisons. New York: Russell Sage Foundation.

- (1978) From Mobilization to Revolution. Reading, MA: Addison-Wesley.

TINGLEY, Donald (1980) The Structuring of a State: The History of Ilinois, 1899-1928. Urbana: University of Illinois Press.

TOHARIA, José Juan (1987) "Pleitos Tengas!" Introduccion a la cultura legal espanola. Madrid: Siglo XXI de Espana.

- (1976) "Economic Development and Litigation: The Case of Spain," 4 Jahrbuch für Rechtssoziologie und Rechtstheorie 25. Presented to the Conference on the Sociology of the Judicial Process, University of Bielefeld, West Germany, 1973.

(1975) "Judicial Independence in an Authoritarian Regime: The Case of Contemporary Spain," 9 Law \& Society Review 475.

(1974) Cambio Social y Vida Juridica en Espana. Madrid: Edicusa.

TRUBEK, David (1980-81a) "Studying Courts in Context," 15 Law \& Society Review 484.

- $(1980-81 \mathrm{~b})$ "The Construction and Deconstruction of a Disputes-focused Approach: An Afterword," 15 Law \& Society Review 727.

(1972), "Max Weber on Law and the Rise of Capitalism," 1972 Wisconsin law Review 720.

TRUBEK, D. M., and GALANTER, M. (1974) "Scholars in Self-Estrangement: Some Reflections on the Crisis in Law and Development Studies," 1974 Wisconsin Law Review 1062.

TURK, Austin T. (1976) "Law as a Weapon in Social Conflict," 23 Social Problems 276.

TURKEL, Gerald (1979) "Testing Durkheim: Some Theoretical Considerations," 13 Law \& Society Review 721.

TYLER, Tom R. (1988) "What Is Procedural Justice? Criteria Used by Citizens to Assess the Fairness of Legal Procedures," 22 Law \& Society Review 103.

UNDERWOOD, Robert (1971) “The Illinois Judicial System," 47 Notre Dame Lawyer 247.

UNGER, Roberto M. (1976) Law in Modern Society: Toward a Criticism of Social Theory. New York: Free Press.

U.S. ADMINISTRATIVE OFFICE OF THE UNITED STATES COURTS (1937-1987) Annual Reports of the Director. Washington, DC: Government Printing Office.

U.S. DEPARTMENT OF JUSTICE, OFFICE OF THE ATTORNEY GENERAL (1908-34) Annual Reports of Attorney General.

- (1916) Instructions to United States Marshalls, Attorneys, Clerks, and Commissioners. (1939) Survey of Release Procedures, Vol. 2.

U.S. DEPARTMENT OF THE TREASURY, BUREAU OF INDUSTRIAL ALCOHOL (1924-33) Statistics Concerning Intoxicating Liquors.

U.S. DEPARTMENT OF THE TREASURY, BUREAU OF PROHIBITION (1930) State Cooperation: Federal and State Responsibility Under the Concurrent Power. (1920-33) Annual Reports.

U.S. GENERAL ACCOUNTING OFFICE (1989) Product Liability: Verdicts and Case Resolutions in Five States. Washington, DC: Government Printing Office.

- (1988) Product Liability: Extent of Litigation Explosion in Federal Courts Questioned. Washington, DC: Government Printing Office.

U.S. NATIONAL COMMISSION ON LAW OBSERVANCE AND ENFORCEMENT (Wickersham Commission) (1931a) Report \#1: Report on the Enforcement of Prohibition Laws of the United States. Doc. 722, 71st Congress, 3d session. 
(1931b) Report \#2: Report on the Enforcement of Prohibition Laws of the United States. Doc. 722, 71st Congress, 3d session.

(1931c) Report \#3: Report on Criminal Statistics.

(1931d) Report \# 7: Progress Report on the Study of the Federal Courts. (1931e) Vol. 5: Enforcement of the Prohibition Laws. Senate Doc. 307, 71st Congress, 3d session.

U.S. OFFICE OF PRICE ADMINISTRATION, OFFICE OF TEMPORARY CONTROLS (1947) "The Beginnings of OPA: The Price Control Act of 1942," General Publication No. 1.

U.S. SENATE, JUDICIARY COMMITTEE (1926) The National Prohibition Law: Hearings before the Subcommittee of the Committee on the Judiciary.

UNITED NATIONS (1987) National Accounts Statistics: Analysis of Main Aggregates, 1983/1984. New York: UN.

UPHAM, Frank (1987) Law and Social Change in Postwar Japan. Cambridge, MA: Harvard University Press.

VALENTINE, David T. (1864) Manual of the Corporation of the City of New York, 1864. New York: New York City Common Council.

VAN DUIJN, Jacob J. (1983) The Long Wave in Economic Life. Boston: Allen \& Unwin.

VAN LOON, F., and E. LANGERWERF (1990) "Socioeconomic Development and the Evolution of Litigation Rates of Civil Courts in Belgium, 1835-1980," 24 Law \& Society Review 283.

(1987) Burgerlijke Rechtbanken: Wie, Wat, Hoe? Antwerp: Kluwer.

VERWOERD, Jan R. A. (1988) "Beroep op de rechter als laatste remedie?" Unpublished dissertation, Arnhem.

VERWOERD, Jan. R. A., and Erhard BLANKENBURG (1985a) "Biotopen in de mobilisering van recht; een vergelijkende studie van de rechtsversorgende systemen in Nederland en de Westduitse deelstaat NordrheinWestfalen." Unpublished paper.

- $(1985 b)$ Comparing Litigation in the Netherlands with That of Northrhine Westphalia in Germany, 1970-1981." Presented at the World Congress of Sociology of Law, Aix-en-Provence, France.

VIDMAR, Neil (1984) "The Small Claims Court: A Reconceptualization of Disputes and an Empirical Investigation," 18 Law \& Society Review 515.

VIRGINIA LAW REVIEW (1947) "Twelve Years with the 'Heart Balm Acts'," 33 Virginia Law Review 314.

VON EYBEN, W. E. (1987) Dommertilkendegivelser. Copenhagen: G. E. C. Gad.

WAGTSUMA, Hiroshi, and Arthur ROSSETT (1986) "The Implications of Apology: Law and Culture in Japan and the United States," 20 Law \& Society Review 461.

WALD, PATRICIA (1983) "The Problem with the Courts: Black-robed Bureaucracy, or Collegiality Under Challenge?" 42 Maryland Law Review 766.

WALES, H. G. Quaritch (1931) Siamese State Ceremonies: Their History and Function. London: Bernard Quaritch.

WALTON, Clarence C., and Frederick W. CLEVELAND (1964) Corporations on Trial: The Electric Cases. Belmont, CA: Wadsworth Publ. Co.

WANNER, Craig (1975) "The Public Ordering of Private Relations, Part Two: Winning Civil Court Cases," 9 Law \& Society Review 293.

- (1974) "The Public Ordering of Private Relations, Part One, Initiating Civil Cases in Urban Trial Courts," 8 Law \& Society Review 421.

WEBER, Max (1967) Max Weber on Law in Economy and Society. Cambridge, MA: Harvard University Press.

WEBER, Nathan (1987) Product Liability: The Corporate Response. New York: Conference Board.

WERLE, Raymond (1982) "Aspekte der Verrechtlichung," 3 Jahrbuch für Rechtssoziologie und Rechtstheorie 2.

WHEELER, Stanton, Bliss CARTWRIGHT, Robert A. KAGAN, and Lawrence M. FRIEDMAN (1987) 'Do the 'Haves' Come Out Ahead? Winning and Losing in State Supreme Courts, 1870-1970," 21 Law \& Society Review 403. 
WHITEHEAD, Don (1956) The FBI Story: A Report to the People. New York: Random House.

WHITFORD, William (1984) "The Small-Case Procedure of the U.S. Tax Court: A Small Claims Court That Works," 1984 American Bar Foundation Research Journal 797.

WHO'S WHO IN JURISPRUDENCE. (1925) Brooklyn, NY: John W. Leonard Corp.

WHO'S WHO IN LAW. (1937) New York: J. C. Schwarz Corp.

WIEACKER, Franz (1967) Privatrechtsgeschichte der Neuzeit. 2d ed. Gottingen: Vandenhoek \& Ruprecht.

WIEBE, Robert H. (1967) The Search for Order. New York: Hill \&Wang.

WIGMORE, J. H. (1937) The Science of Judicial Proof: As Given by Logic, Psychology, and General Experience and Mlustrated in Judicial Trials. 3d ed. Boston: Little, Brown.

WIJEYEWARDENE, Gehan (1970) "The Still Point and the Turning World: Towards the Structure of Northern Thai Religion," 7 Mankind 247.

WILKIE, James W., and Adam PERKAL (eds.) (1984) Statistical Abstract of Latin America, Vol. 23. Los Angeles: UCLA Latin American Center Publications.

WILLEBRANDT, Mobel Walker (1929) The Inside of Prohibition. Indianapolis: Bobbs-Merrill.

WILLGING, Thomas (1987) Trends in Asbestos Litigation. Washington, DC: Federal Judicial Center.

WILLIAMSON, Oliver E. (1979) "Transaction-Cost Economics. The Governance of Contractual Relations," 22 Journal of Law and Economics 233.

(1985) Economic Institutions of Capitalism: Firms, Markets, Relational Contracting. New York: Free Press.

WIMBERLY, Howard (1973) "Legal Evolution: One Further Step," 79 American Journal of Sociology 78.

WIPPLER, Richard, and Siegwart LINDENBERG (1987) "Collective Phenomena and Rational Choice," in J. C. Alexander, B. Giesen, R. Munch, and N. J. Smelser (eds.), The Micro-Macro Link. Berkeley: University of California Press.

WOLFE, Alan (1977) The Limits of Legitimacy: Political Contradictions of Contemporary Capitalism. New York: Free Press.

WOLLSCHLÄGER, Christian (1990) "Civil Litigation and Modernization: The Work of The Municipal Courts of Bremen, Germany in Five Centuries, 1549-1984," 24 Lawo \& Society Review 261.

(1989) "Die Arbeit der europäischen Zivilgerichte im historischen und internationalen Vergleich. Zeitreihen der europäisch en Zivilprozessflut seit dem 19. Jahrhundert," in Erhard Blankenburg (ed.), Prozessflut? Studien zur Prozesstätigkeit europäischer Gerichte in historischen Zeitreihen und im Rechtsvergleich. Cologne: Bundesanzeiger.

(1985) "Time Series of Litigation in Europe since the Nineteenth Century." Presented at the Annual Meeting of the Law and Society Association, San Diego, CA.

- (1982) "Ungleiche Justizgewähr und Zivilprozesshäufigkeit in der preussischen Ständigesellschaft um 1750," in N. Horn (ed.), Europäisches Rechtsdenken in Geschichte und Gegenwart. Festschrift für H. Coing, vol. 1. Munich: Beck.

(1981) "Zivilprozess-Statistik und Wirtschaftsentwicklung in Preussen im 18. und 19. Jahrhundert," Zeitschrift für neuere Rechtsgeschichte 16.

YALE LAW JOURNAL (1956) "The Influence of the Defendant's Plea on Judicial Determination of Sentence," 66 Yale Law Journal 204.

YNGVESSON, Barbara (1990) "Contextualizing the Court: Comment on the Cultural Study of Litigation," 24 Law \& Society Review 467.

(1988) "Making Law at the Doorway: The Clerk, the Court, and the Construction of Community in a New England Town," 22 Law \& Society Review 409.

(1985a) "Re-examining Continuing Relations and the Law," 1985 Wisconsin Law Review 623.

(1985b) "Legal Ideology and Community Justice in the Clerk's Office," 9 Legal Studies Forum 71.

(1982) "What Is a Dispute About? The Political Interpretation of Social 
Control," in Donald Black (ed.) Toward a General Theory of Social Control, Vol. 2. New York: Academic Press.

YNGVESSON, Barbara, and Lynn MATHER (1983) "Courts, Moots, and the Disputing Process," in Keith O. Boyum and Lynn Mather (eds.), Empirical Theories About Courts. New York: Longman.

YNGVESSON, Barbara, and Patricia HENNESSEY (1975) "Small Claims, Complex Disputes: A Review of the Small Claims Literature," 9 Law \& Society Review 219.

YOHAI, Victor, Werner ACKERMANN, and H. HAIGH (1985) "Nonlinear Principal Components," 19 Quality and Quantity 53.

ZEMANS, Francis Kahn (1983) "Legal Mobilization: The Neglected Role of the Law in the Political System," 77 American Political Science Review 690.

(1982) "Framework for Analysis of Legal Mobilization: A Decisionmaking Model," 1982 American Bar Foundation Research Journal 989.

ZUCKERMAN, S., C. R. KOLLER, and R. R. BORBJERG (1986) "Information on Malpractice: A Review of Empirical Research on Major Policy Issues," 49 (no. 2) Law and Contemporary Problems 85.

\section{LIST OF CASES CITED}

Bram v. United States, 168 U.S. 532 (1897).

Cipollone v. Liggett Group, Inc., 83-2864 (D.N.J., 1988), rev'd 88-5732 (C.A.3, Jan. 5, 1990).

Kercheval v. United States, 274 U.S. 220 (1927).

Motor Vehicle Manufacturers Association v. State Farm Mutual Automobile Insurance, 463 U.S. 29 (1983).

People v. Gowasky, 219 A.D. 19 (1926).

Tarasoff $v$. Regents of the University of California, 13 Cal. 3d 177, 529 P.2d 553, 118 Cal. Rptr. 129 (1974), withdrawn and replaced by 17 Cal. 3d 425, 551 P.2d 334, 131 Cal. Rptr. 14 (1976).

United States v. Alphonse Capone (1931) Cases \# 22852 \& 23232: Transcript of Consolidation Hearing on July 30, 1931, Box RG21, National Archives, Chicago, Illinois.

Walters v. National Association of Radiation Survivors, 473 U.S. 305, 105 S. Ct. 3180, 87 L. Ed. 2d 220 (1985).

Wight $v$. Rindskopf, 43 Wis. 344 (1877) 
